\title{
Influence of the representation of convection on the mid-Holocene West African Monsoon
}

\author{
Leonore Jungandreas ${ }^{1}$, Cathy Hohenegger ${ }^{1}$, and Martin Claussen ${ }^{1,2}$ \\ ${ }^{1}$ Max Planck Institute for Meteorology, Bundesstraße 53, 20146 Hamburg, Germany \\ ${ }^{2}$ Center for Earth System Research and Sustainability, Universität Hamburg, Bundesstraße 53, 20146 Hamburg, Germany
}

Correspondence: Leonore Jungandreas (leonore.jungandreas@ mpimet.mpg.de)

Received: 21 December 2020 - Discussion started: 26 January 2021

Revised: 26 April 2021 - Accepted: 11 May 2021 - Published: 5 August 2021

\begin{abstract}
Global climate models experience difficulties in simulating the northward extension of the monsoonal precipitation over north Africa during the mid-Holocene as revealed by proxy data. A common feature of these models is that they usually operate on grids that are too coarse to explicitly resolve convection, but convection is the most essential mechanism leading to precipitation in the West African Monsoon region. Here, we investigate how the representation of tropical deep convection in the ICOsahedral Nonhydrostatic (ICON) climate model affects the meridional distribution of monsoonal precipitation during the mid-Holocene by comparing regional simulations of the summer monsoon season (July to September; JAS) with parameterized and explicitly resolved convection.

In the explicitly resolved convection simulation, the more localized nature of precipitation and the absence of permanent light precipitation as compared to the parameterized convection simulation is closer to expectations. However, in the JAS mean, the parameterized convection simulation produces more precipitation and extends further north than the explicitly resolved convection simulation, especially between 12 and $17^{\circ} \mathrm{N}$. The higher precipitation rates in the parameterized convection simulation are consistent with a stronger monsoonal circulation over land. Furthermore, the atmosphere in the parameterized convection simulation is less stably stratified and notably moister. The differences in atmospheric water vapor are the result of substantial differences in the probability distribution function of precipitation and its resulting interactions with the land surface. The parametrization of convection produces light and large-scale precipitation, keeping the soils moist and supporting the development of convection. In contrast, less frequent but lo-
\end{abstract}

cally intense precipitation events lead to high amounts of runoff in the explicitly resolved convection simulations. The stronger runoff inhibits the moistening of the soil during the monsoon season and limits the amount of water available to evaporation in the explicitly resolved convection simulation.

\section{Introduction}

During the mid-Holocene, around 9000 to 6000 years before present (BP), the landscape of the today's extremely arid Sahara was transformed into a widespread savannahlike landscape characterized by grass- and shrublands (Jolly et al., 1998), variable tree cover and permanent lakes and wetlands (Tierney et al., 2017). This remarkable transformation of the Sahara, which is commonly called "Green Sahara", can be attributed to an intensified West African Monsoon (WAM) (Kutzbach and Otto-Bliesner, 1982; Kutzbach and Liu, 1997). The intensification of the WAM circulation was driven by a higher summer insolation in the Northern Hemisphere during the mid-Holocene (Kutzbach and Guetter, 1986; Street-Perrott et al., 1990). Reconstructions of precipitation from proxy data (Peyron et al., 2006; Bartlein et al., 2011) indicate around 200 to $700 \mathrm{~mm} \mathrm{yr}^{-1}$ more precipitation over the Sahel-Saharan region during this humid period. However, global general circulation models (GCMs) capture neither the reconstructed mean precipitation (Yu and Harrison, 1996; Braconnot et al., 2012) nor the change in precipitation between the coastal regions of Africa and the arid Sahel-Sahara for the mid-Holocene (Joussaume et al., 1999; Braconnot et al., 2012; Harrison et al., 2015; Brierley et al., 2020). Compared to reconstructions, most climate models 
(e.g., used in PMIP3 and PMIP4) are able to reproduce the precipitation amount over the Sahel but produce too little precipitation north of $15^{\circ} \mathrm{N}$, resulting in an overly strong meridional precipitation gradient.

The reasons for the mismatch between climate models and reconstructions are still debated. Feedback mechanisms between the land/vegetation (e.g., Kutzbach and Liu, 1997; Claussen and Gayler, 1997; Braconnot et al., 1999, 2012; Claussen et al., 2017), ocean (e.g., Kutzbach and Liu, 1997; Hewitt and Mitchell, 1998; Braconnot et al., 1999, 2012) and the atmosphere are known to enhance the orbitally induced increase in mid-Holocene monsoonal precipitation (Joussaume et al., 1999; Braconnot et al., 2012). A better representation of the land surface in GCMs may be necessary to substantially increase precipitation levels (e.g., Levis et al., 2004; Vamborg et al., 2010). As another factor, changes in dust fluxes between present-day and mid-Holocene conditions have been mentioned and are a subject of controversy (Pausata et al., 2016; Thompson et al., 2019). Finally, by adding an artificial heating source within the atmospheric boundary layer over the Sahara, Dixit et al. (2018) were able to increase the magnitude and northward extent of precipitation comparable to what is seen in proxy data. They argued that GCMs miss an important local diabatic heating source over the Sahel-Saharan region.

The parameterization of convection poses another limitation for GCMs. For most, if not all, paleosimulations, GCMs usually operate on relatively coarse horizontal resolution $(\sim 200 \mathrm{~km})$, where convection is not explicitly resolved. Several studies (Yang and Slingo, 2001; Randall et al., 2003; Stephens et al., 2010; Dirmeyer et al., 2012; Fiedler et al., 2020) have shown that simulations with parameterized convection are not able to reproduce many key characteristics of the present-day precipitation distribution, such as the location of the Intertropical Convergence Zone (ITCZ), the propagation of the monsoon or the diurnal cycle of precipitation. Also, they produce rainfall that is both too much and too light.

This raises the question as to whether convectionpermitting simulations can improve the representation of the WAM and the precipitation distribution for mid-Holocene climate conditions. Support for this hypothesis comes from the study by Marsham et al. (2013). For present-day conditions, they conducted short (covering only $10 \mathrm{~d}$ ) simulations with explicitly resolved convection and parameterized convection for a regional domain located in northwest Africa. In their study, the monsoonal precipitation propagated further northward and peaked between 10 to $12^{\circ} \mathrm{N}$ in their simulation with explicit convection, in better agreement with observations. They ascribed the improvement of the precipitation pattern to the better representation of the diurnal cycle of convection.

Using the ICON-NWP model (ICOsahedral Nonhydrostatic model framework for numerical weather prediction), we investigate how the representation of convection impacts the mid-Holocene WAM. We perform parameterized and explicitly resolved convection simulations with prescribed midHolocene atmospheric initial and boundary conditions for two entire monsoon seasons. The main aim of the study is to test whether explicitly resolving convection leads to a stronger northward propagation of the WAM during the midHolocene.

The paper is structured as follows: we describe the model and different simulation setups in Sect. 2. In Sect. 3, we present and explain the simulated precipitation patterns. A summary and conclusion follow in Sect. 4.

\section{Methods}

\subsection{Model}

We use the ICON model framework version 2.5.0 (Zängl et al., 2015) in its operational NWP mode. ICON was developed through a collaboration between the Max Planck Institute for Meteorology and the German Weather Service. The model has already been used and evaluated with respect to tropical convection and circulation by several studies (e.g., Klocke et al., 2017; Stevens et al., 2019; Hohenegger et al., 2020). Zängl et al. (2015) lists the physical parameterizations of the model framework. The parameterization of convection is based on the bulk mass-flux approach introduced by Tiedtke (1989) with modifications by Bechtold et al. (2014). We will switch the convective parameterization on or off, depending on the grid spacing. Our limited-area simulations are forced with initial and boundary data from a transient global Holocene simulation, previously conducted with the Max Planck Institute Earth System Model (MPI-ESM) and covering the years from $8000 \mathrm{BP}$ (before present, where the year 2000 is used as the reference) to $150 \mathrm{BP}$. Dallmeyer et al. (2020) describes the performance of the transient MPI-ESM Holocene simulations in detail. Furthermore, we prescribe 6-hourly sea surface temperature (SST) and sea ice (SIC) fields originating from the transient Holocene simulations. The orbital parameters and the tracer gases, carbon dioxide $\left(\mathrm{CO}_{2}\right)$, methane $\left(\mathrm{CH}_{4}\right)$ and nitrogen oxide $\left(\mathrm{N}_{2} \mathrm{O}\right)$, reflect mid-Holocene conditions, as in the MPI-ESM Holocene simulation. Concerning the description of the land surface and vegetation, we take the external parameters from reanalysis data of the Integrated Forecast System (IFS) of the European Centre for Medium-Range Weather Forecasts (ECMWF). Similar to the setup of the simulations in the first Paleoclimate Modelling Intercomparison Project (PMIP; i.e., Joussaume et al., 1999; Braconnot et al., 2000, 2004), the external data reflect present-day conditions. By using present-day surface conditions in this study, we, for a first step, ignore the enhancement of precipitation due to extended vegetation and wetter soil moisture conditions. Furthermore, with a higher vegetation cover, the atmosphere-soil hydrology interactions are also likely to change substantially. Plants enhance the infiltration of water into the soil and increase the interception 
storage of water. Therefore, they increase evapotranspiration into the atmosphere from interception and by transpiration of water from deeper soil layers.

\subsection{Simulation setup}

Firstly, we perform a 30-year "spinup" simulation on a regional domain (see Fig. 1) with $40 \mathrm{~km}$ horizontal grid spacing and 75 vertical levels. The spinup simulation runs for the period 7039 to $7010 \mathrm{BP}$. The convective parameterization is active in this simulation. After around 15 years, the soil moisture equilibrates to a stable state. We choose 2 years after the 15-year spinup phase and perform several nesting experiments for the boreal summer monsoon season. The nesting experiments are initialized for 30 May and run for 5 months (June to October; JJASO). The parent domain of the nested simulation is identical to the domain of the spinup simulation with the same horizontal and vertical resolution. The nesting configuration then reduces the horizontal grid spacing by a factor of 2 down to the $5 \mathrm{~km}$ horizontal resolution (Fig. 1). The nested simulations with 40, 20 and $10 \mathrm{~km}$ grid spacing are run with parameterized convection. In the following, we refer to these simulations as the 40 , the 20 and the $10 \mathrm{~km}-\mathrm{P}$ simulations. The $5 \mathrm{~km}$ simulations resolve convection explicitly and are referred to as the $5 \mathrm{~km}$-E simulations. We simulate with a one-way nesting strategy. The nested simulations are initialized $1 \mathrm{~h}$ after another. Lateral boundary conditions for the nested simulations are obtained from their parent simulation and updated every $6 \mathrm{~h}$.

For each nesting suite, we perform two simulations: one for the year $7023 \mathrm{BP}$ and one for the year $7019 \mathrm{BP}$. We selected these 2 years from the spinup simulation based on the simulated mean precipitation (Fig. 2a) and the mean meridional distribution of precipitation (Fig. 2b) within each year from June to October and over land points of the $5 \mathrm{~km}$ domain (Fig. 1). We chose the year $7023 \mathrm{BP}$ as it displays a combination of generally higher precipitation amounts and slightly higher precipitation rates at latitudes north of $15^{\circ} \mathrm{N}$ relative to the other simulated spinup years. The year $7019 \mathrm{BP}$, in contrast, gives the combination of slightly weaker precipitation amounts and weaker precipitation rates north of $15^{\circ} \mathrm{N}$ compared to most of the other years of the spinup simulation.

Marsham et al. (2013) identified the difference in the simulated precipitation diurnal cycle between explicitly resolved and parameterized convection as the main reason for the different meridional distributions of precipitation for their simulations under present-day conditions. In contrast to Marsham et al. (2013) and to GCMs used in PMIP, the convective parameterization used in the operational setup of ICON-NWP simulates the peak of diurnal convection in the late afternoon instead of noon in agreement with observations, due to modifications introduced by Bechtold et al. (2014). Thus, the timing of the precipitation diurnal cycle in simulations with explicit and parameterized convection is similar in our case (Fig. 3a). To test the importance of the timing of the diurnal cycle of precipitation for the representation of the monsoon propagation during the mid-Holocene, we perform a second set of nested simulations where we removed the modifications by Bechtold et al. (2014). In this simulation with the modified diurnal cycle, the convection peaks around noon, as expected (Fig. 3b). Even though the diurnal cycle of the $5 \mathrm{~km}$-E simulation is not directly modified in this second set of nested simulations, comparing this simulation to our control simulation reveals small differences because the two $5 \mathrm{~km}-\mathrm{E}$ simulations are driven by the $40 \mathrm{~km}-\mathrm{P}$ simulations with different diurnal cycles, respectively. In the following, simulations with the modified diurnal cycle are labeled with "mod" (Sect. 3.6).

We perform a third suite of nested simulations to separate the impact of resolution on the WAM from the impact of the representation of convection. In these simulations, the 20 and $10 \mathrm{~km}$ simulations are run with explicitly resolved convection. These simulations are referred to as the 20 and $10 \mathrm{~km}-\mathrm{E}$ simulations. We compare these with the 20 and $10 \mathrm{~km}-\mathrm{P}$ simulations.

\section{Results and discussion}

\subsection{Precipitation distribution}

During the mid-Holocene, the northward propagation of precipitation constitutes the main difference to today's precipitation pattern. As described in the introduction, reconstructions point towards less precipitation over equatorial Africa and the Sahel region but substantially more precipitation over the Sahara. Therefore, we are mainly interested in the meridional precipitation gradient which modulates the landscape and vegetation cover of the north African continent.

In the JJASO simulations with ICON-NWP, we identify July to September (JAS) as the strongest monsoon months. Therefore, we mainly focus our analysis on these 3 months. Furthermore, as the simulations for the two years (7023 BP and $7019 \mathrm{BP}$ ) reveal similar results, we only show the results for $7023 \mathrm{BP}$.

Figure $4 \mathrm{a}$ clearly shows that the $40 \mathrm{~km}-\mathrm{P}$ simulation produces more precipitation and precipitation that reaches further north than the $5 \mathrm{~km}-\mathrm{E}$ simulation. On average and from 12 to $17^{\circ} \mathrm{N}$, it rains $0.8 \mathrm{~mm} \mathrm{~d}^{-1}$ more in the $40 \mathrm{~km}-\mathrm{P}$ simulation than in the $5 \mathrm{~km}-\mathrm{E}$ simulation at each latitude. Over 5 months, this sums up to over $120 \mathrm{~mm}$ per latitude which could already impact the vegetation cover. A secondary precipitation peak is also visible around $15^{\circ} \mathrm{N}$ in the $40 \mathrm{~km}-\mathrm{P}$ simulation, a peak that is absent in the $5 \mathrm{~km}$-E simulation. The fact that the parameterized simulation produces more precipitation is not only true for the $40 \mathrm{~km}-\mathrm{P}$ simulation but also for all grid spacings where parameterized convection is used.

Figure $4 \mathrm{a}$ also shows that the mean meridional distribution of monsoonal precipitation is predominantly determined 


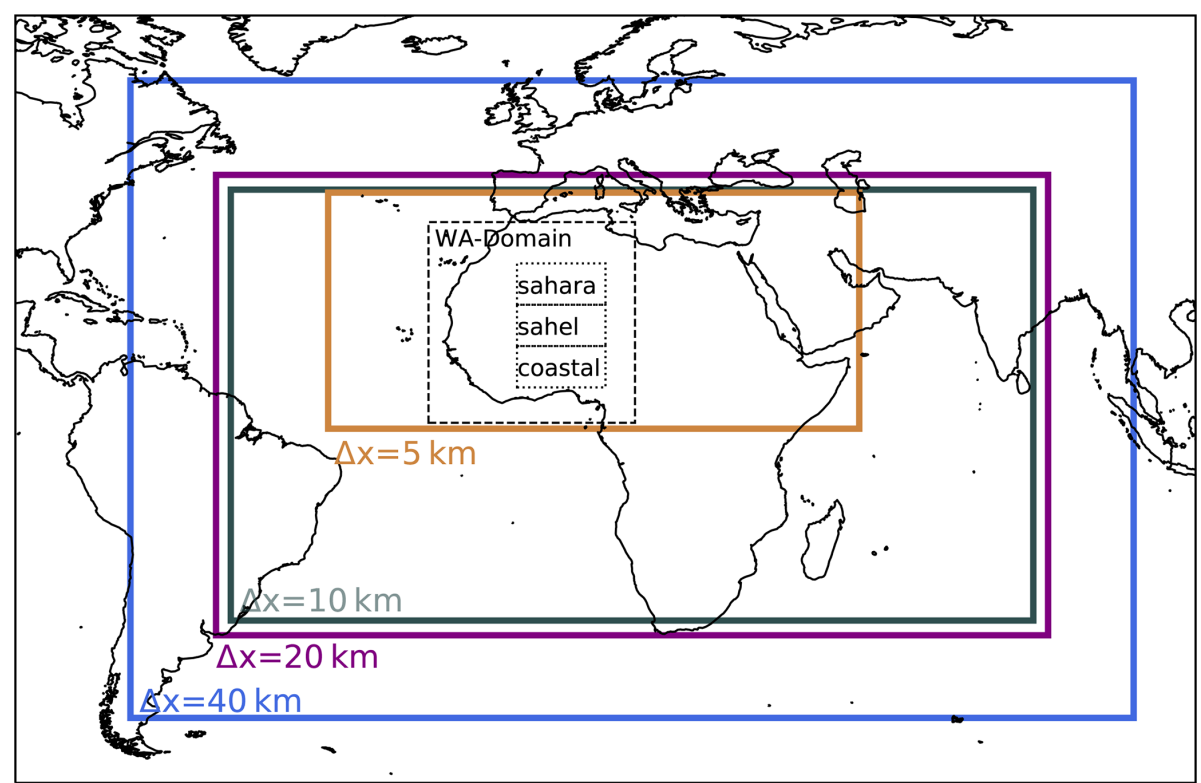

Figure 1. Colored domains display the nesting domains of the simulations for the various grid spacings (as indicated). The dashed black domain with the label "WA domain" (west Africa) shows the analysis domain for Figs. 3, 4, 6, 8, and 10 and spans the area from $1-35^{\circ} \mathrm{N}$ and from $20^{\circ} \mathrm{E}-15^{\circ} \mathrm{W}$. The three dotted black domains over north Africa are used to calculate the skew-T diagrams for the coastal African region ("coastal"), the Sahel region ("Sahel") and the Saharan region ("Sahara") in Fig. 7. The coastal region spans from 6-14 ${ }^{\circ}$ N and from $5^{\circ} \mathrm{E}-10^{\circ} \mathrm{W}$. The Sahel region spans from $14-21^{\circ} \mathrm{N}$ and from $5^{\circ} \mathrm{E}-10^{\circ} \mathrm{W}$ and the Sahara region from $21-28^{\circ} \mathrm{N}$ and from $5^{\circ} \mathrm{E}-10^{\circ} \mathrm{W}$.
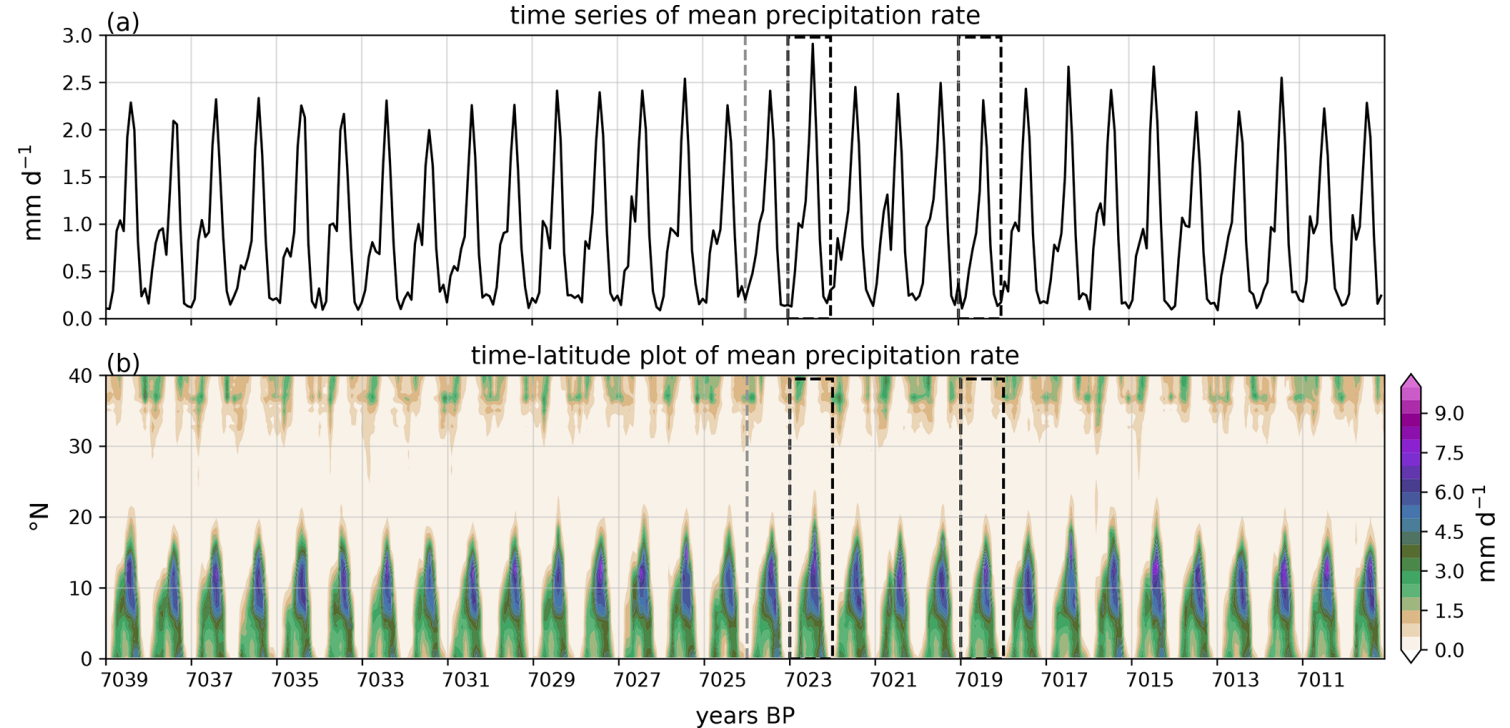

Figure 2. The 30-year time series of the mean precipitation rate (a) and the latitude-time plot of the mean precipitation rate over land (b) indicating the northward extension of the WAM every year for the whole $5 \mathrm{~km}$ domain spanning the area from $0-40^{\circ} \mathrm{N}$ and from $37^{\circ} \mathrm{E}-$ $53^{\circ} \mathrm{W}$. The dashed light-gray line indicates the end of the spinup phase when soil moisture is on a constant level. The dashed rectangles show the years we chose for our analysis: 7023 BP (strong) and 7019 BP (weak).

by the representation of convection rather than the resolution. This becomes visible by comparing the $10 \mathrm{~km}-\mathrm{P}$ and the $10 \mathrm{~km}-\mathrm{E}$ simulations. The $10 \mathrm{~km}-\mathrm{P}$ simulation is more similar to the $40 \mathrm{~km}-\mathrm{P}$ simulation than to the $10 \mathrm{~km}-\mathrm{E}$ simulation. Conversely, the $10 \mathrm{~km}-\mathrm{E}$ simulation is more similar to the
$5 \mathrm{~km}-\mathrm{E}$ simulation than to $10 \mathrm{~km}-\mathrm{P}$. This is also valid for the $20 \mathrm{~km}-\mathrm{P}$ and $20 \mathrm{~km}-\mathrm{E}$ simulations (not shown). Given these similarities and the fact that grid spacings finer than $5 \mathrm{~km}$ are typically employed when conducting convection-permitting simulations, we focus our analysis on the $40 \mathrm{~km}-\mathrm{P}$ and $5 \mathrm{~km}-$ 

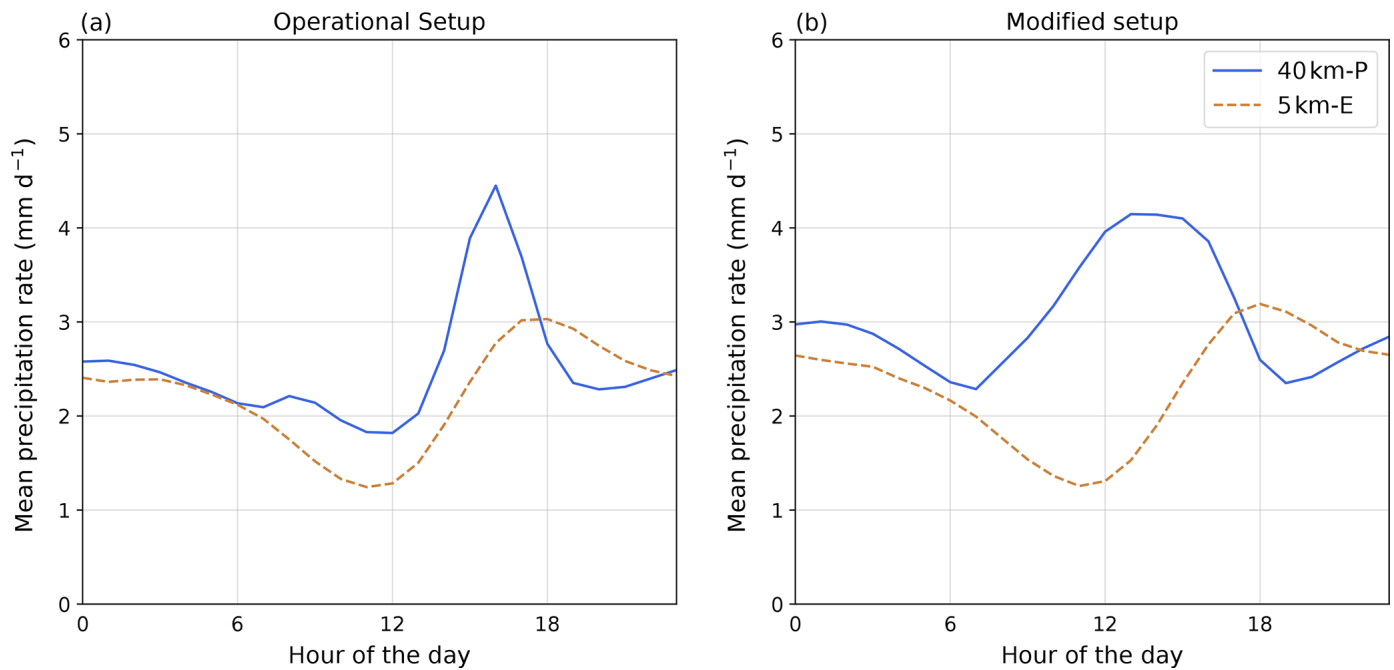

Figure 3. Mean diurnal cycle of precipitation for the $40 \mathrm{~km}-\mathrm{P}$ (solid blue) and the $5 \mathrm{~km}-\mathrm{E}$ (dashed orange) simulation for July to September (JAS). (a) The diurnal cycle for the operational ICON-NWP model; (b) the diurnal cycle of the modified ICON-NWP setup used in Sect. 3.6. The diurnal cycle is calculated over the dashed "WA domain" outlined in Fig. 1.
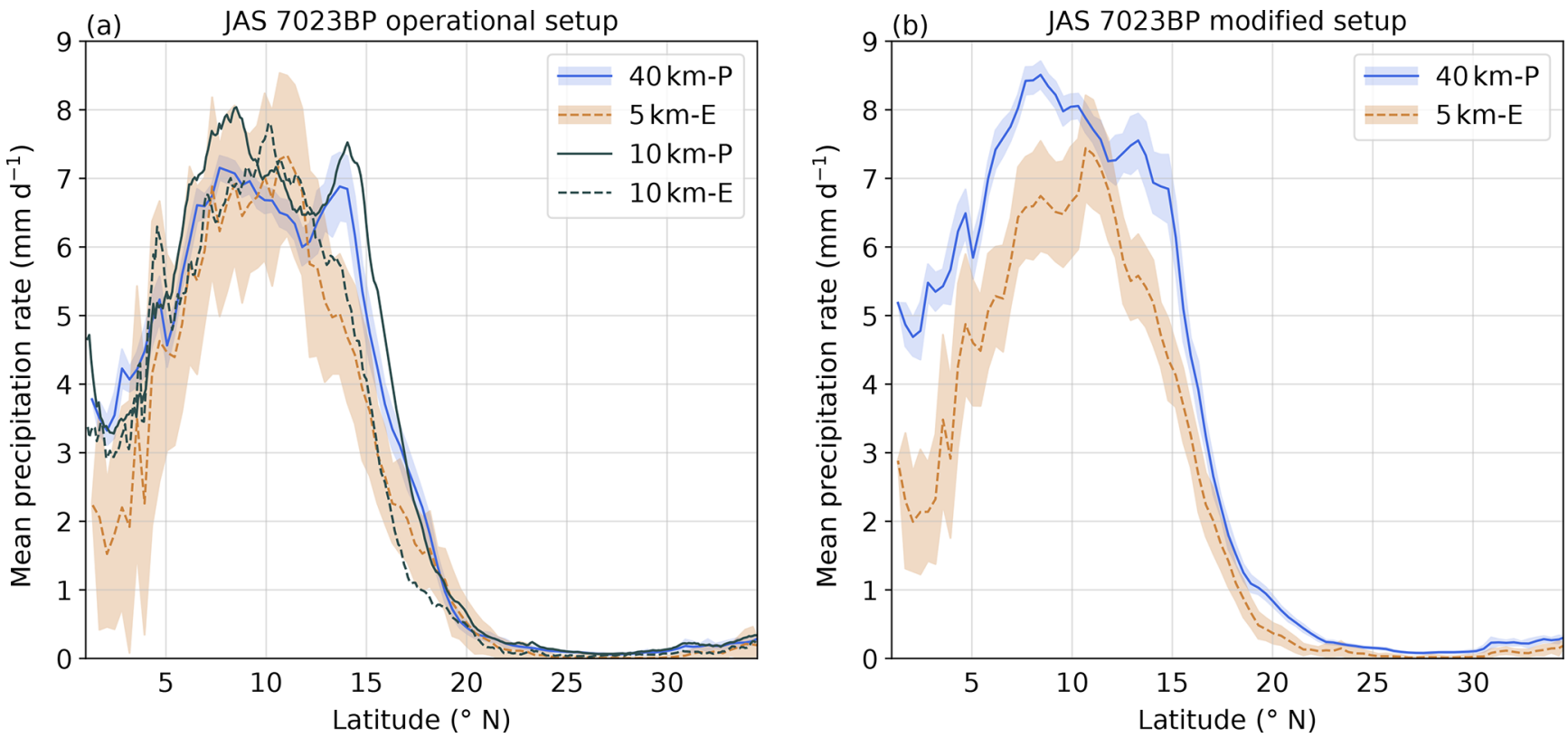

Figure 4. Meridional distribution of monsoonal precipitation for (a) the operational simulations and (b) the setup with modified diurnal cycle (analyzed in Sect. 3.6) for the $40 \mathrm{~km}-\mathrm{P}$ (solid blue), the $5 \mathrm{~km}-\mathrm{E}$ (dashed orange), the $10 \mathrm{~km}-\mathrm{P}$ (solid black) and the $10 \mathrm{~km}-\mathrm{E}$ (dashed black) simulations. The shading displays the daily longitudinal mean standard deviation from the longitudinal mean JAS cycle for the $40 \mathrm{~km}-\mathrm{P}$ and the $5 \mathrm{~km}-\mathrm{E}$ simulation. The longitudinal mean is taken over the land points of the WA domain outlined in Fig. 1.

E simulations. The analysis was repeated for the $10 \mathrm{~km}-\mathrm{P}$ and $10 \mathrm{~km}-\mathrm{E}$ simulations and can be found in Appendix A.

In the following, we begin by analyzing the large-scale mean state of the atmosphere by examining the pressure field and the large-scale dynamics of the WAM circulation to understand the precipitation differences (Sect. 3.2). We then investigate whether and how the thermodynamic structure of the atmosphere supports the development of convec- tion and precipitation in the $40 \mathrm{~km}-\mathrm{P}$ and $5 \mathrm{~km}-\mathrm{E}$ simulations (Sect. 3.3). As this analysis points to strong differences in the moisture field between the $40 \mathrm{~km}-\mathrm{P}$ and the $5 \mathrm{~km}-\mathrm{E}$ simulations, we examine in the following two sections differences in moisture transport (Sect. 3.4) and differences in evapotranspiration (Sect. 3.5), the two moisture sources for precipitation. Finally, we test whether the diurnal cycle of convection 
impacts the propagation of the WAM over north Africa as suggested by Marsham et al. (2013) (Sect. 3.6).

\subsection{Large-scale circulation}

To understand the unexpectedly stronger precipitation in the $40 \mathrm{~km}-\mathrm{P}$ simulation compared to the $5 \mathrm{~km}-\mathrm{E}$ simulation, we start with the analysis of the large-scale circulation characteristics. The WAM winds are predominantly driven by the near-surface pressure gradient between the heat low over the warm African continent and the high pressure system over the colder Gulf of Guinea (Thorncroft et al., 2011; Nicholson, 2013).

The pressure gradient between the Saharan heat low (SHL) and the high pressure system over the Gulf of Guinea is stronger in the $5 \mathrm{~km}-\mathrm{E}$ simulation. This can be seen in Fig. 5, which shows the mean $925 \mathrm{hPa}$ geopotential height and the mean wind field at $925 \mathrm{hPa}$ for the $40 \mathrm{~km}-\mathrm{P}$ and $5 \mathrm{~km}-\mathrm{E}$ simulations, respectively. The stronger high pressure system over the tropical Atlantic in the $5 \mathrm{~km}-\mathrm{E}$ simulation compared to the $40 \mathrm{~km}-\mathrm{P}$ simulation leads to a stronger pressure gradient in the Gulf of Guinea and to stronger winds in the Gulf of Guinea (Fig. 5c). These winds in the Gulf of Guinea modulate the moisture transport into central Africa and support a stronger monsoon in the $5 \mathrm{~km}-\mathrm{E}$ simulation, which cannot directly explain our previous findings of a weaker monsoon propagation in the $5 \mathrm{~km}-\mathrm{E}$ simulation.

In contrast, the pressure gradient between the subtropical east Atlantic and the SHL are stronger in the $40 \mathrm{~km}-\mathrm{P}$ simulation. In the latter simulation, the SHL and the high pressure system in the subtropical east Atlantic are stronger compared to the $5 \mathrm{~km}-\mathrm{E}$ simulation. In addition to the stronger pressure systems, the SHL extends further west in the $40 \mathrm{~km}-\mathrm{P}$ than in $5 \mathrm{~km}-\mathrm{E}$ simulation, leading to an even stronger pressure gradient along the coast of Morocco and in the subtropical east Atlantic. The stronger pressure gradient accelerates the wind along the coast of Morocco and Western Sahara in the $40 \mathrm{~km}-\mathrm{P}$ simulation (Fig. 5c) and results in a stronger wind convergence in the tropical Atlantic along $10^{\circ} \mathrm{N}$. This wind convergence is important for the moisture transport into the Western Sahara. The stronger winds along $10^{\circ} \mathrm{N}$ indicate a stronger moisture transport into this region in the $40 \mathrm{~km}-\mathrm{P}$ than in the $5 \mathrm{~km}-\mathrm{E}$ simulation.

The northward propagation of precipitation during the West African Monsoon depends not only on the strength of the southwesterly low-level monsoon flow but also on the strength of the Harmattan and the vertical lifting of air masses throughout the troposphere. The northerlies associated with the hot and dry Harmattan winds are stronger in the $5 \mathrm{~km}-\mathrm{E}$ than in the $40 \mathrm{~km}-\mathrm{P}$ simulation and counteract more strongly against the southerly monsoon flow. This surface convergence zone between the southerly monsoon flow and the northerly Harmattan is known as the Intertropical Front (ITF). In the $5 \mathrm{~km}-\mathrm{E}$ simulation, the ITF is located further south at around 17 to $18^{\circ} \mathrm{N}$, while in the $40 \mathrm{~km}-\mathrm{P}$ simulation it is located at around $20^{\circ} \mathrm{N}$ (Fig. 6). The more northerly location of the ITF, as well as the generally weaker northward component against and above the surface monsoon winds, support the development of convection and therefore the higher precipitation rates further north in the $40 \mathrm{~km}-\mathrm{P}$ than in the $5 \mathrm{~km}$-E simulation (Fig. 4a).

In the JAS mean, the vertical wind is stronger in the $40 \mathrm{~km}$ P simulation compared to the $5 \mathrm{~km}$-E simulation (Fig. 6). Additionally, the ascent region is broader in the $40 \mathrm{~km}-\mathrm{P}$ simulation compared to the $5 \mathrm{~km}-\mathrm{E}$ simulation. This, on average, stronger and broader ascent region is consistent with stronger precipitation in the $40 \mathrm{~km}-\mathrm{P}$ simulation as opposed to the $5 \mathrm{~km}$-E simulation.

The strongest vertical velocities are located between 5 and $15^{\circ} \mathrm{N}$ in the $40 \mathrm{~km}-\mathrm{P}$ simulation and between 8 and $15^{\circ} \mathrm{N}$ in the $5 \mathrm{~km}$-E simulation. They are associated with the lifting between the tropical easterly jet at around $5^{\circ} \mathrm{N}$ and at $200 \mathrm{hPa}$ height and the African easterly jet (AEJ) at around $16^{\circ} \mathrm{N}$ and at $600 \mathrm{hPa}$ height. A second weaker updraft region is located between 17 and $20^{\circ} \mathrm{N}$ and is associated with the lifting of air masses at the ITF. We want to comment on the fact that we find a slightly weaker AEJ in the $5 \mathrm{~km}$ E simulation compared to the $40 \mathrm{~km}-\mathrm{P}$ simulation. For example, Cook (1999) and Nicholson and Grist (2001) associated a weaker AEJ with wetter conditions over Africa in present-day conditions, which is contradictory to our results. Grist and Nicholson (2001) and Nicholson and Grist (2001) suggest that the location of the AEJ is more important than its intensity. They link a more northern location of the AEJ core with higher rainfall and rainfall further north. Figure 6 shows that the AEJ core in our simulations is located slightly further north in the $40 \mathrm{~km}-\mathrm{P}$ than in the $5 \mathrm{~km}-\mathrm{E}$ simulation. This is consistent with the higher precipitation rates and the slightly stronger northward extension of monsoonal rainfall in the $40 \mathrm{~km}-\mathrm{P}$ compared to the $5 \mathrm{~km}-\mathrm{E}$ simulation and with the findings from Grist and Nicholson (2001) and Nicholson and Grist (2001).

In conclusion, the stronger horizontal monsoon circulation (southwesterlies), the more northward location of the ITF, as well as the stronger and broader ascent region in the $40 \mathrm{~km}-\mathrm{P}$ simulation as compared to the $5 \mathrm{~km}$-E simulation, are all consistent with a stronger monsoon and a more northward propagation, in agreement with Fig. 4. Only the pressure gradient between the Gulf of Guinea and the SHL is stronger in the $5 \mathrm{~km}$-E simulation. As will be shown later, the stronger pressure gradient between the Gulf of Guinea and the SHL does transport more moisture onto the African continent in the $5 \mathrm{~km}$-E simulation, an effect nevertheless overcompensated by an excessively strong local drying of the African continent due to high amounts of runoff (see Sects. 3.4 and 3.5).

\subsection{Thermodynamics}

The large-scale monsoon circulation supports the higher precipitation rates in the $40 \mathrm{~km}-\mathrm{P}$ simulation than in the $5 \mathrm{~km}-\mathrm{E}$ 

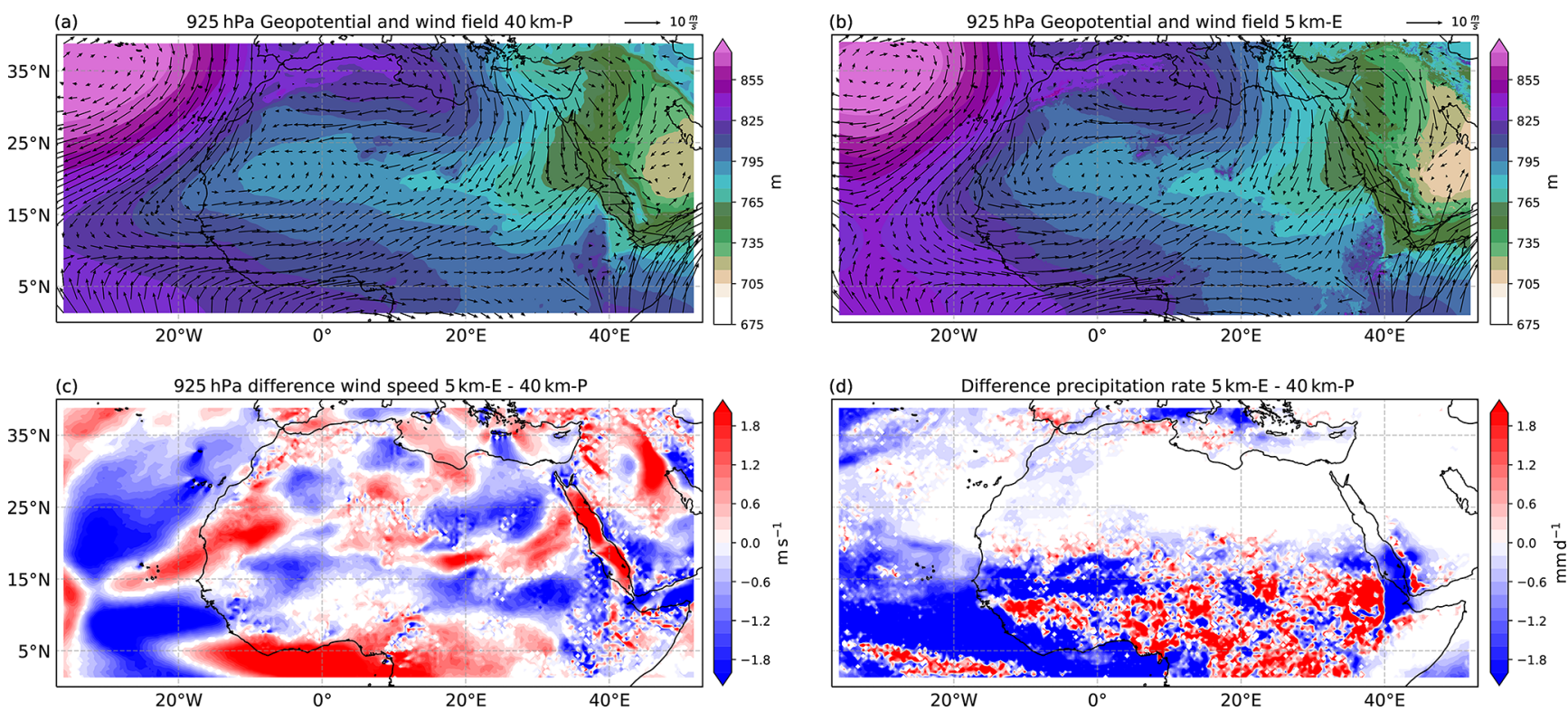

Figure 5. JAS mean geopotential height (shading) and mean wind field (vectors; $\mathrm{ms}^{-1}$ ) at $925 \mathrm{hPa}$ for the $40 \mathrm{~km}-\mathrm{P}$ (a) and the $5 \mathrm{~km}-\mathrm{E}$ simulations (b), the difference in JAS mean wind speed at $925 \mathrm{hPa}$ (c) and the difference in JAS mean precipitation rate (d) between the $5 \mathrm{~km}-\mathrm{E}$ and $40 \mathrm{~km}-\mathrm{P}$ simulations, respectively. White colors in panels (c, d) display difference values between -0.1 and 0.1 .
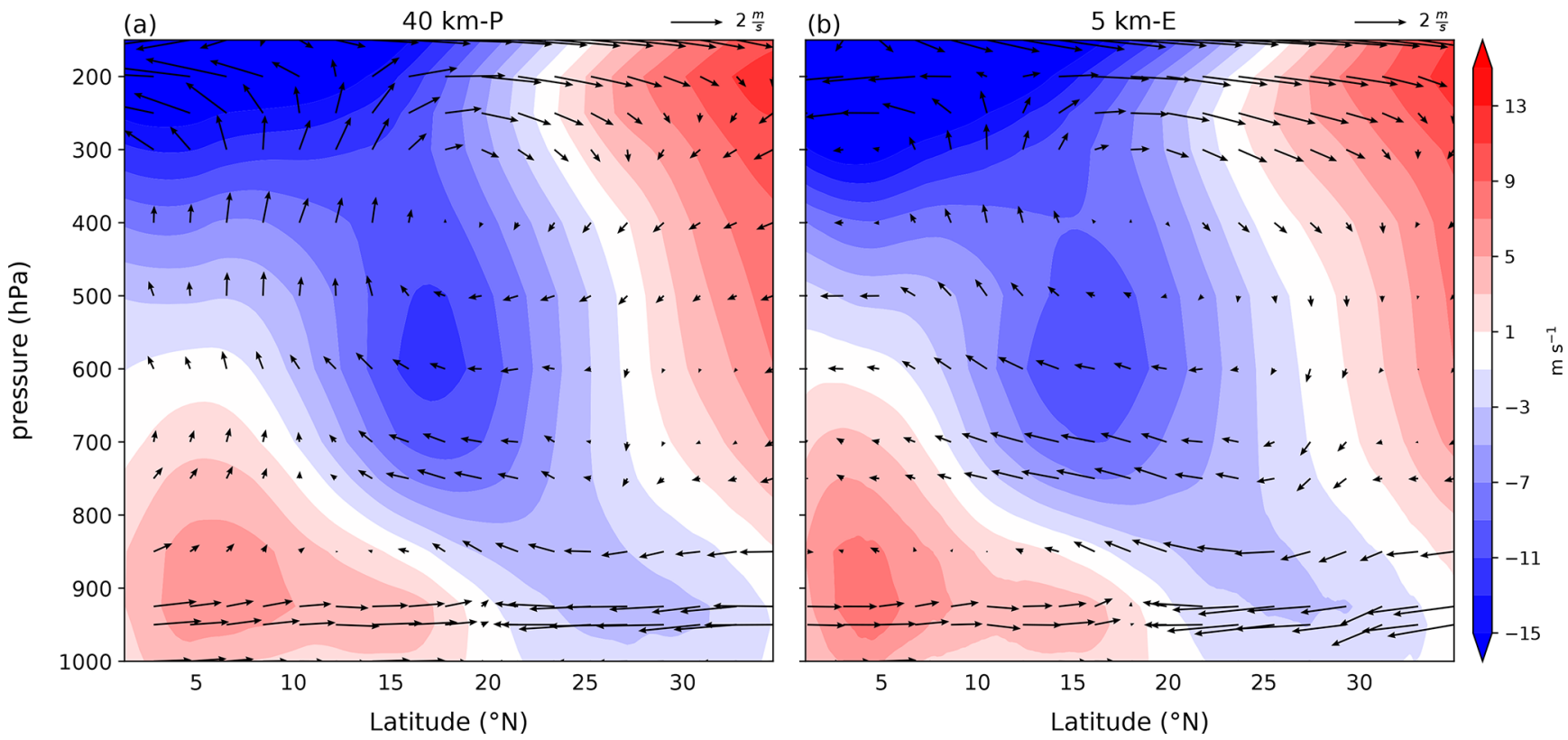

Figure 6. JAS mean cross section of the zonally averaged wind field for the $40 \mathrm{~km}-\mathrm{P}$ (a) and for the $5 \mathrm{~km}-\mathrm{E}$ simulation (b). The shading shows the zonal wind in $\mathrm{ms}^{-1}$. The vectors show the meridional and vertical wind field $\left(\mathrm{ms}^{-1}\right)$, where the vertical wind component is multiplied with 100 to make the vectors better visible. The mean is taken over all points of the dashed "WA domain" outlined in Fig. 1.

simulation. However, if and how the prevailing atmospheric conditions lead to the development of convection and precipitation are essentially determined by the thermodynamic structure of the atmosphere. To investigate this, we examine the thermodynamical profiles for both representations of convection. We look at thermodynamical profiles for three different regions of north Africa as outlined in Fig. 1: the "coastal" region, the "Sahel" region and the "Sahara" region. Figure 7 shows the corresponding thermodynamical profiles for 8 September 7023 BP at 12:00 UTC. We choose 8 September as being representative of the prevalent state of 
Table 1. JAS mean values of CAPE, CIN and dew-point depression for the coastal, Sahel and Sahara regions (Fig. 1).

\begin{tabular}{llrr}
\hline & & $40 \mathrm{~km}-\mathrm{P}$ & $5 \mathrm{~km}-\mathrm{E}$ \\
\hline \multirow{2}{*}{ Coastal } & $\mathrm{CAPE}\left(\mathrm{J} \mathrm{kg}^{-1}\right)$ & 877.9 & 869.6 \\
& $\mathrm{CIN}\left(\mathrm{J} \mathrm{kg}^{-1}\right)$ & -27.1 & -43.6 \\
& $T-T_{d}\left({ }^{\circ} \mathrm{C}\right)$ & 5.1 & 6.1 \\
\hline \multirow{2}{*}{ Sahel } & $\mathrm{CAPE}\left(\mathrm{J} \mathrm{kg}^{-1}\right)$ & 868.8 & 431.3 \\
& $\mathrm{CIN}\left(\mathrm{J} \mathrm{kg}^{-1}\right)$ & -172.0 & -221.5 \\
& $T-T_{d}\left({ }^{\circ} \mathrm{C}\right)$ & 13.4 & 17.3 \\
\hline \multirow{2}{*}{ Sahara } & $\mathrm{CAPE}\left(\mathrm{J} \mathrm{kg}^{-1}\right)$ & 46.8 & 11.9 \\
& $\mathrm{CIN}\left(\mathrm{J} \mathrm{kg}^{-1}\right)$ & -120.8 & -65.8 \\
& $T-T_{d}\left({ }^{\circ} \mathrm{C}\right)$ & 30.6 & 32.8 \\
\hline
\end{tabular}

the atmosphere for both representations of convection during JAS, as confirmed with Table 1 .

The thermodynamic profiles over the coastal region show a higher level of convective inhibition (CIN) in the $5 \mathrm{~km}-\mathrm{E}$ simulation compared to the $40 \mathrm{~km}-\mathrm{P}$ simulation. As both the $40 \mathrm{~km}-\mathrm{P}$ and the $5 \mathrm{~km}-\mathrm{E}$ simulation have similar mean surface temperatures around $26^{\circ} \mathrm{C}$ and mean dew-point temperatures of around $21^{\circ} \mathrm{C}$, the higher CIN in the $5 \mathrm{~km}$-E simulation is a result of a more stably stratified atmosphere between 900 and $700 \mathrm{hPa}$. Combined with the weaker prevailing vertical velocity in the $5 \mathrm{~km}$-E simulation (see Sect. 3.2), we conclude that convection can be less easily triggered in the $5 \mathrm{~km}-\mathrm{E}$ simulation.

The atmospheric conditions get even less supportive of convection in the $5 \mathrm{~km}-\mathrm{E}$ simulation, when approaching the Sahara region. Over the Sahel, the $5 \mathrm{~km}-\mathrm{E}$ simulation becomes even drier, consistent with a much higher surface temperature and low dew point. The combination of a warm temperature profile and a low dew-point temperature raises the lifting condensation level (LCL) and the level of free convection (LFC). Therefore, even if convection is triggered in the $5 \mathrm{~km}-\mathrm{E}$ simulation, clouds will not deepen past $400 \mathrm{hPa}$ height. From this, we would expect only little precipitation. The $40 \mathrm{~km}-\mathrm{P}$ simulation stays moister in the Sahel region compared to the $5 \mathrm{~km}-\mathrm{E}$ simulation. Moreover, the LCL in the $40 \mathrm{~km}-\mathrm{P}$ simulation is lower and the convection, if triggered, can become very deep. The resulting precipitation is likely to be stronger than in the $5 \mathrm{~km}-\mathrm{E}$ simulation.

Over the Sahara, both the $40 \mathrm{~km}-\mathrm{P}$ and the $5 \mathrm{~km}-\mathrm{E}$ simulations become even drier and surface temperatures rise. The lack of moisture and the stably stratified atmosphere in both simulations reveal that it becomes very unlikely that convection is triggered and precipitation develops in this region.

Table 1 lists the mean values of CAPE, CIN and the dewpoint depression for the three regions to emphasize that the results are valid over the whole JAS season. These findings emphasize that the moisture availability and the thermodynamical state of the atmosphere are much more supportive of the development of convection in the $40 \mathrm{~km}-\mathrm{P}$ simulation than in the $5 \mathrm{~km}-\mathrm{E}$ simulation. Together with the stronger vertical motion in the $40 \mathrm{~km}-\mathrm{P}$ simulation (see Sect. 3.2), this is consistent with the higher precipitation rates in the $40 \mathrm{~km}-\mathrm{P}$ simulation. Furthermore, this suggests that, besides the large-scale circulation and the stability of the atmosphere, the availability of moisture in the two simulations also contributes to the differences in precipitation. We turn our attention to the availability of moisture in the $40 \mathrm{~km}-\mathrm{P}$ and the $5 \mathrm{~km}-\mathrm{E}$ simulations in the next two sections.

\subsection{Moisture field and moisture transport}

The thermodynamical profiles revealed more humid conditions in the $40 \mathrm{~km}-\mathrm{P}$ simulation compared to the $5 \mathrm{~km}$-E simulation, especially in the semi-arid transition zone of the Sahel region. Now, we investigate the moisture field in more detail. The moisture field supports the findings from the previous section that the $40 \mathrm{~km}-\mathrm{P}$ simulation is overall moister over the continent than the $5 \mathrm{~km}-\mathrm{E}$ simulation (Fig. 8). The vertical cross section of specific humidity in Fig. 8a and b shows higher amounts of water vapor in the planetary boundary layer in the $40 \mathrm{~km}-\mathrm{P}$ simulation compared to the $5 \mathrm{~km}-\mathrm{E}$ simulation, especially between 15 and $25^{\circ} \mathrm{N}$. This region coincides with the region where we found higher precipitation rates in the $40 \mathrm{~km}-\mathrm{P}$ than in the $5 \mathrm{~km}-\mathrm{E}$ simulation. Above $900 \mathrm{hPa}$, the specific humidity exhibits similar values in both simulations.

The vertical cross section of relative humidity displays a deep core of moist air at around $8^{\circ} \mathrm{N}$ in both simulations, extending from the surface into the upper troposphere. This region coincides with the region of the strongest vertical velocities (Fig. 6). Throughout the troposphere, the moisture in the deep core exceeds $50 \%$, whereas over the Sahara, the relative humidity is much lower. Comparing the two simulations, the $40 \mathrm{~km}-\mathrm{P}$ simulation shows higher values of relative humidity throughout the depth of the troposphere. This would tend to favor precipitation in the $40 \mathrm{~km}-\mathrm{P}$ simulation.

There are two possible mechanisms for supplying moisture for precipitation over the continent: (1) advection of moisture from surrounding regions and (2) local evapo(transpi)ration (see Sect. 3.5). This provides two possible explanations for the on-average wetter atmosphere in the $40 \mathrm{~km}-\mathrm{P}$ simulation. The north African continent receives more moisture through the moisture transport from the ocean and/or moisture recycling over land is more effective in the $40 \mathrm{~km}-\mathrm{P}$ than in the $5 \mathrm{~km}-\mathrm{E}$ simulation.

First, we look at the moisture transport. Figure 9 shows the JAS vertically integrated moisture flux magnitude and moisture flux for the $40 \mathrm{~km}-\mathrm{P}$ and the $5 \mathrm{~km}-\mathrm{E}$ simulations. We integrate the lower atmosphere levels from 1000 to $850 \mathrm{hPa}$. The stronger winds in the tropical Atlantic in the $40 \mathrm{~km}-\mathrm{P}$ simulation (see Fig. 5c and Sect. 3.2), which are associated with the African westerly jet, result in a stronger moisture transport from this region into the west Sahel-Saharan region 

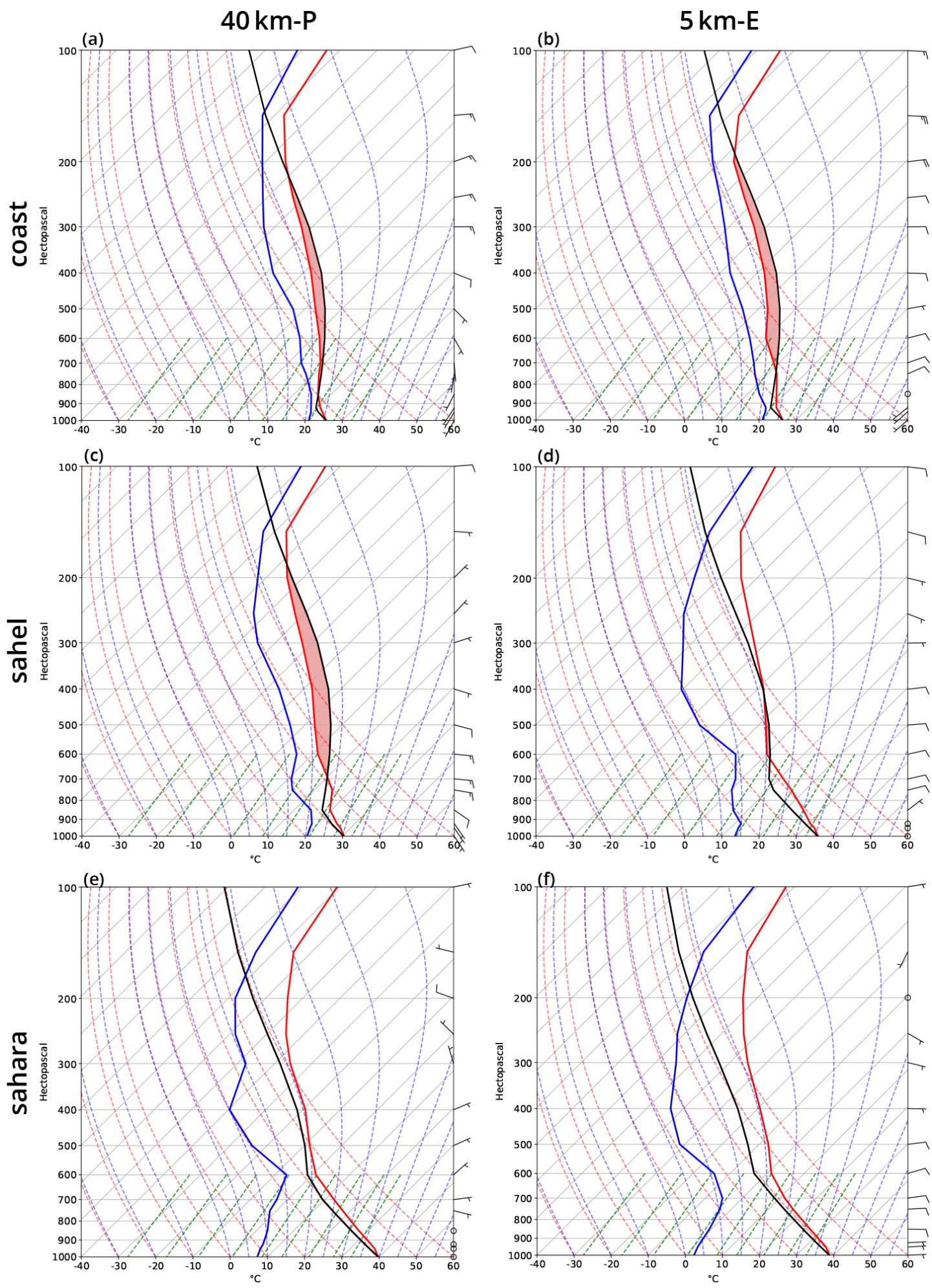

Figure 7. Skew-T diagrams for 8 September 7023 BP 12:00 UTC for the $40 \mathrm{~km}-\mathrm{P}(\mathbf{a}, \mathbf{c}, \mathbf{e})$ and the $5 \mathrm{~km}-\mathrm{E}$ (b, d, f) simulations. The red line depicts the temperature profile, the blue line the dew point and the black line the path an air parcel would take through the atmosphere. The profiles are averaged over the three domains outlined in Fig. 1 labeled with "coast", "Sahel" and "Sahara". The red-shaded area displays the CAPE. The lines in the background refer to the dry adiabats (dashed red), moist adiabats (dashed blue), isotherms (solid gray tilted) and isobars (solid gray horizontal). 

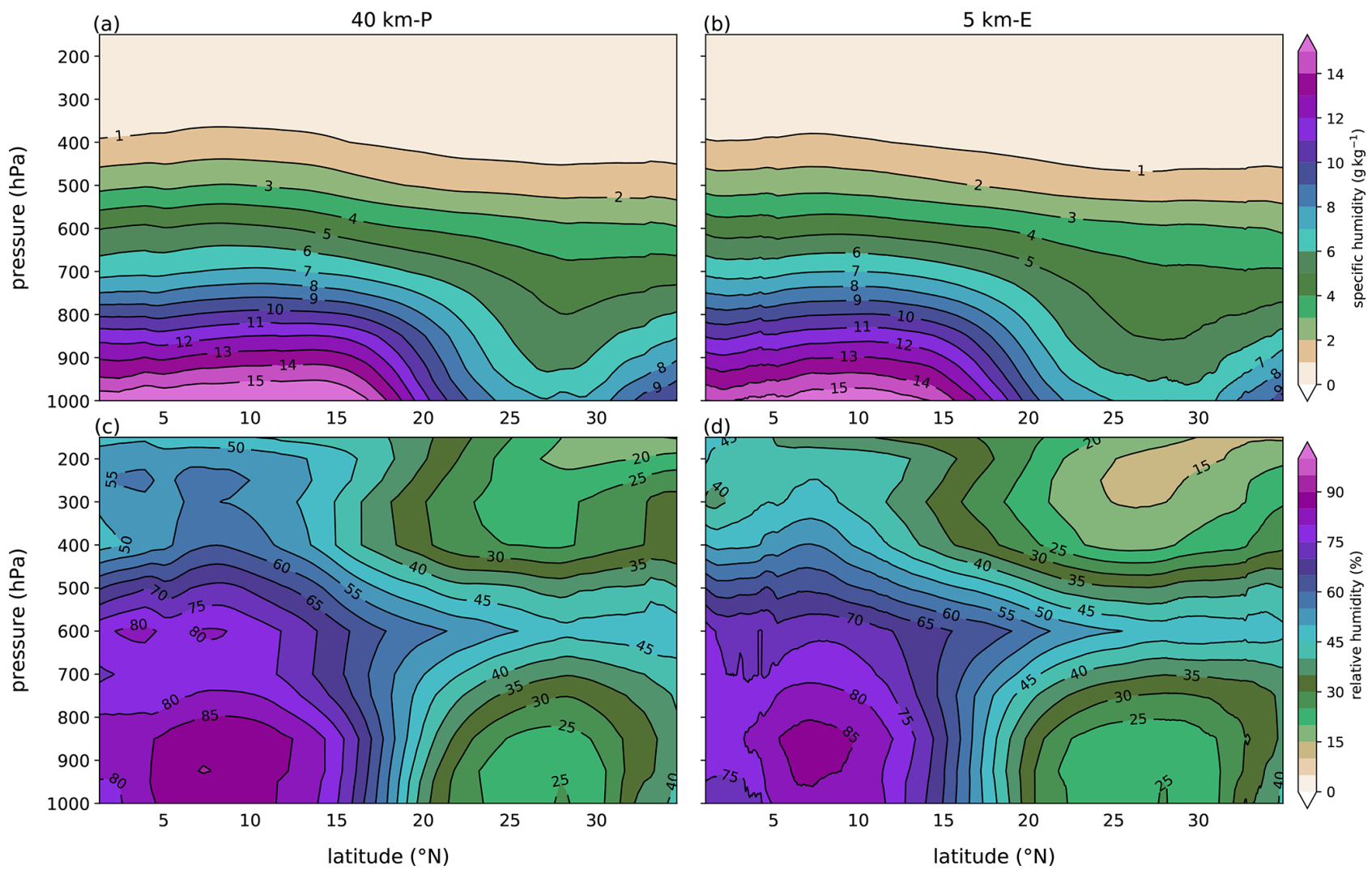

Figure 8. JAS mean vertical cross section of specific humidity in $\mathrm{g} \mathrm{kg}^{-1}$ in the two upper panels (a, b) and for relative humidity in $\%$ in the two bottom panels (c, d) for the $40 \mathrm{~km}-\mathrm{P}(\mathbf{a}, \mathbf{c})$ and the $5 \mathrm{~km}-\mathrm{E}(\mathbf{b}, \mathbf{d})$ simulations, respectively. The mean is taken over land of the "WA domain" (dashed domain) outlined in Fig. 1.
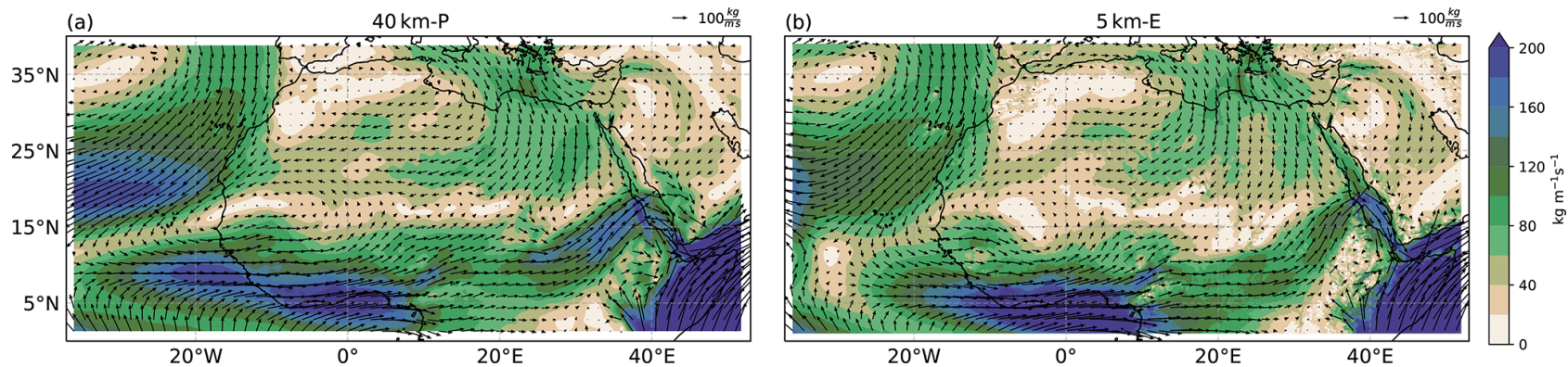

Figure 9. JAS 1000 to $850 \mathrm{hPa}$ vertically integrated moisture flux magnitude (shading) and mean vertically integrated moisture flux (vectors; $\mathrm{kg} \mathrm{m}^{-1} \mathrm{~s}^{-1}$ ) for the $40 \mathrm{~km}-\mathrm{P}$ (a) and the $5 \mathrm{~km}-\mathrm{E}$ (b) simulations.

compared to the $5 \mathrm{~km}-\mathrm{E}$ simulation. Furthermore, the moisture transport originating from the Mediterranean Sea towards the Sahara is stronger in the $40 \mathrm{~km}-\mathrm{P}$ simulation compared to the $5 \mathrm{~km}-\mathrm{E}$ simulation. However, and more importantly, the moisture transport from the Gulf of Guinea, which supplies moisture dominantly into central north Africa, is stronger in the $5 \mathrm{~km}-\mathrm{E}$ simulation compared to the $40 \mathrm{~km}$ $\mathrm{P}$ simulation due to the stronger winds in this region (compare to Fig. 5c and Sect. 3.2). The result that the tropical Atlantic along $10^{\circ} \mathrm{N}$ and the Gulf of Guinea supply moisture for the west Sahel-Saharan region and central-north Africa, respectively, is consistent with the results from Druyan and Koster (1989) and Lélé et al. (2015) for present-day conditions. Over the WA domain, the domain-mean moisture flux is 84.2 and $81.8 \mathrm{~kg} \mathrm{~m}^{-1} \mathrm{~s}^{-1}$ for the $40 \mathrm{~km}-\mathrm{P}$ and the $5 \mathrm{~km}$ E simulations, respectively. Hence, in a mean sense, there is a slightly larger domain-mean moisture flux over the WA domain in the $40 \mathrm{~km}-\mathrm{P}$ simulation compared to the $5 \mathrm{~km}-\mathrm{E}$ simulation. 


\subsection{Land-atmosphere coupling}

Besides the moisture transport from the ocean and humid coastal regions into north Africa, the local source of moisture due to evapotranspiration needs to be considered as well. The evapotranspiration (Fig. 10a) coincides with the precipitation rates (Fig. $4 \mathrm{a}$ ) in the $40 \mathrm{~km}-\mathrm{P}$ and the $5 \mathrm{~km}-\mathrm{E}$ simulations. In other words, between the Equator and $8^{\circ} \mathrm{N}$, the evapotranspiration is higher in the $40 \mathrm{~km}-\mathrm{P}$ simulation than in the $5 \mathrm{~km}$-E simulation. Between 8 and $12^{\circ} \mathrm{N}$, evapotranspiration is equally strong in both simulations, and north of $12^{\circ} \mathrm{N}$ it becomes larger in the $40 \mathrm{~km}-\mathrm{P}$ simulation again. The regions of higher evapotranspiration in the $40 \mathrm{~km}-\mathrm{P}$ simulation reflect the higher precipitation rates in the $40 \mathrm{~km}-\mathrm{P}$ simulation compared to the $5 \mathrm{~km}-\mathrm{E}$ simulation.

The evaporation is strongly coupled to soil moisture, especially in regions with sparse or no vegetation. The soil moisture up to $1.62 \mathrm{~m}$ depth is much lower in the $5 \mathrm{~km}-\mathrm{E}$ simulation compared to the $40 \mathrm{~km}-\mathrm{P}$ simulation especially during our analysis period from July to September (Fig. 10b). The lower soil moisture in the $5 \mathrm{~km}-\mathrm{E}$ simulation is due to higher amounts of total runoff (Fig. 10c) compared to the $40 \mathrm{~km}-\mathrm{P}$ simulation. The higher runoff is due to both higher surface and higher groundwater runoff, where groundwater runoff refers to the subsurface runoff in all soil layers. The ratio between surface and groundwater runoff is higher in the $5 \mathrm{~km}$-E compared to the $40 \mathrm{~km}-\mathrm{P}$ simulation, as it is expected from the precipitation characteristics (see next paragraph). The high amount of runoff in the $5 \mathrm{~km}-\mathrm{E}$ simulation prevents the remoistening of the soil by precipitation, maintaining low levels of soil moisture and leading to an overly dry and warm atmosphere for convection to develop efficiently. Based on results from Savenije (1996), the runoff plays a key role for the recycling of water over semi-arid regions (i.e., the SahelSaharan region).

The differences in the amount of runoff in the $40 \mathrm{~km}-\mathrm{P}$ and the $5 \mathrm{~km}-\mathrm{E}$ simulation are driven by substantial differences in the characteristics of the precipitation distribution. Figure $10 \mathrm{~d}$ displays the probability that a simulation produces dominantly light (low rain rates) or stronger precipitation events (high rain rates). The figure reveals that in the parameterized simulations it is much more likely to produce light rainfall $\left(<15 \mathrm{~mm} \mathrm{~d}^{-1}\right)$, while the simulation with explicitly resolved convection exhibits much more intense precipitation events $\left(>15 \mathrm{mmd}^{-1}\right)$. The light rainfall in the $40 \mathrm{~km}-\mathrm{P}$ simulation is widespread over the whole domain, while the precipitation in the $5 \mathrm{~km}$-E simulation occurs more locally (not shown). High amounts of precipitation in a short time interval and over a small area in the $5 \mathrm{~km}-\mathrm{E}$ simulation lead to the high amounts of runoff, as the water uptake by the soil is limited. On the contrary, in the $40 \mathrm{~km}-\mathrm{P}$ simulation, the constantly light and large-scale precipitation sufficiently moistens the soil throughout the simulation period.

\subsection{Diurnal cycle}

Marsham et al. (2013) identified the difference in the timing of the precipitation diurnal cycle between parameterized and explicit convection as the main driver for the differences in the meridional distribution of precipitation in their presentday simulations. We test whether this effect has an impact in our simulations. We find that the precipitation in the $40 \mathrm{~km}-\mathrm{P}$ modified ("MOD") setup is neither weaker nor shifted further southward compared to the $5 \mathrm{~km}-\mathrm{E}$ and the $40 \mathrm{~km}-\mathrm{P}$ simulation (Fig. 4b). Moreover, the $40 \mathrm{~km}-\mathrm{P}_{\text {MOD }}$ simulation exhibits even more precipitation, especially between the Equator and $15^{\circ} \mathrm{N}$ compared to the other simulations. We conclude that a later precipitation peak does not favor a more northward propagation of precipitation in our model framework, as was the case in Marsham et al. (2013).

The differences between our results and the results of Marsham et al. (2013) can be due to various aspects related to the model and simulation setup. Firstly, the model Marsham et al. (2013) used utilizes a different convective parameterization than ICON-NWP. ICON-NWP uses the same convection scheme as the IFS, a convection scheme that has been continuously developed and tuned to best match today's precipitation distribution.

Secondly, the analyzed period in our study is 3 months, while Marsham et al. (2013) focused on a $10 \mathrm{~d}$ period. They chose their simulation period during the peak of the monsoon season from the end of July until the beginning of August. We also find $15 \mathrm{~d}$ periods in our simulations where the $5 \mathrm{~km}-\mathrm{E}$ simulation propagates further north than the $40 \mathrm{~km}-\mathrm{P}$ simulation. This suggests that the northward extent of monsoonal precipitation is very variable on short timescales.

Thirdly, we simulate a much larger domain, covering the whole north African continent and parts of the Atlantic Ocean, while Marsham et al. (2013) focused on a smaller land-only domain from $10^{\circ} \mathrm{E}$ to $10^{\circ} \mathrm{W}$ and 5 to $25^{\circ} \mathrm{N}$. The latter two facts imply that different characteristics and amounts of precipitation from different regions in Africa, as well as the large-scale circulation and effects from the Atlantic ocean influence our analysis. These effects are not captured in the study of Marsham et al. (2013). Berthou et al. (2019) performed a 10-year study comparing simulations with explicit and parameterized convection performed with the Met Office Unified Model. This is the same model which was used in Marsham et al. (2013). In the 10-year mean, the simulations with explicitly resolved convection did not show a substantially stronger northward extent of precipitation than the parameterized ones, a result closer to our findings.

\section{Summary and conclusion}

In this study, we investigated whether the representation of convection (parameterized versus explicit) impacts the meridional distribution of monsoonal rainfall under mid- 

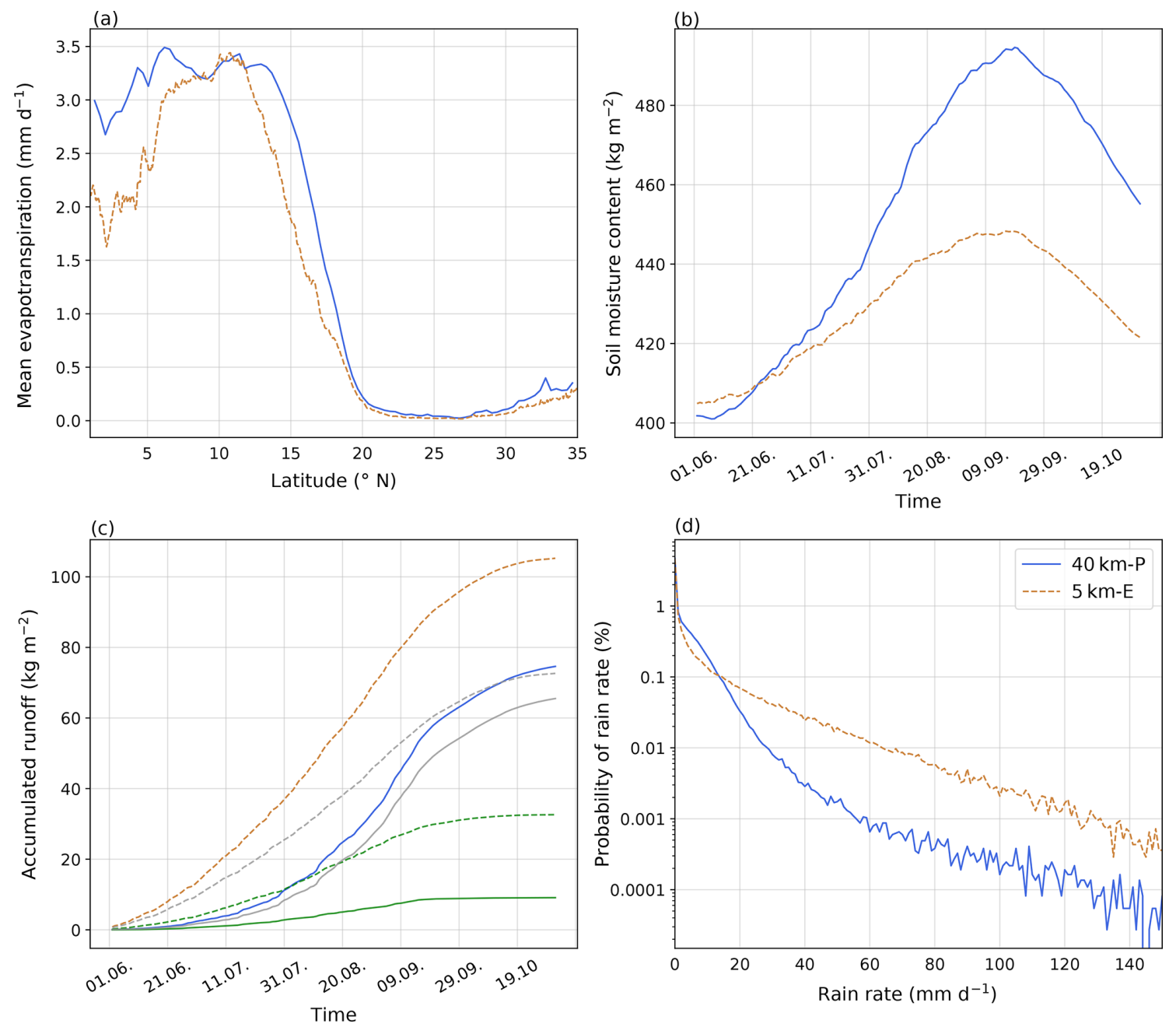

Figure 10. (a) JAS mean meridional distribution of evaporation (b) time series of soil water content: sum over the first six layers (1.62 m), (c) JJASO time series of accumulated runoff, surface runoff (green lines) and groundwater runoff (gray lines), (d) probability density function (PDF) of JAS mean rain rate for the $40 \mathrm{~km}-\mathrm{P}$ (solid blue) and the $5 \mathrm{~km}-\mathrm{E}$ (dashed orange) simulation excluding days with rain rates equal to $0 \mathrm{~mm} \mathrm{~d}^{-1}$. All calculations are performed over land of the dashed "WA domain" outlined in Fig. 1.

Holocene atmospheric conditions (i.e., orbital parameters, tracer gases) over north Africa. For that purpose, we ran regional nested simulations with the atmospheric model, ICON-NWP. To analyze the meridional distribution of precipitation in both settings, we compared $40 \mathrm{~km}$ parameterized $(40 \mathrm{~km}-\mathrm{P})$ with $5 \mathrm{~km}$ explicitly resolved convection $(5 \mathrm{~km}-\mathrm{E})$ simulations. Furthermore, we isolated the impact of different resolutions from those of different representations of convection by comparing $10 \mathrm{~km}$ parameterized $(10 \mathrm{~km}-$ $\mathrm{P})$ and explicitly resolved convection (10 km-E) simulations. In agreement with the results of previous studies conducted for present-day conditions (Marsham et al., 2013; Dirmeyer et al., 2012; Pearson et al., 2014), the precipitation distributions across simulations with the same representation of convection are more similar than those simulations with the same grid spacing.
Marsham et al. (2013) found a stronger northward propagation of precipitation in explicit convection simulations compared to the parameterized simulation for present-day conditions. This motivated our study and raised the following question: does the representation of convection also impact the northward extent of the WAM during the mid-Holocene? In the JAS mean, our $40 \mathrm{~km}-\mathrm{P}$ simulation produces around $0.8 \mathrm{~mm} \mathrm{~d}^{-1}$ per latitude more precipitation north of $12^{\circ} \mathrm{N}$ than the $5 \mathrm{~km}$-E simulation. As such, the representation of convection does impact the northward extent of the WAM but in an opposite way than initially thought, with a stronger propagation in the parameterized simulation. Compared to the results of Marsham et al. (2013), this is mainly because the parametrization of convection in ICON-NWP produces already a more realistic meridional distribution of precipitation than the Met Office Unified Model. 
The differences in the meridional precipitation distribution between explicitly resolved convection and parameterized convection in our simulations are caused by three factors:

- We identified a generally stronger monsoonal circulation over the north African continent in the $40 \mathrm{~km}-\mathrm{P}$ than in the $5 \mathrm{~km}$-E simulation. The near-surface southwesterly monsoon flow over land is stronger in the $40 \mathrm{~km}$ $\mathrm{P}$ than in the $5 \mathrm{~km}-\mathrm{E}$ simulation. Furthermore, in the $5 \mathrm{~km}-\mathrm{E}$ simulation, the northerlies from the hot and dry Harmattan counteract more strongly the monsoonal winds. These northerlies push the ITF southward. We also found that the (positive) vertical component of the wind field is, in the JAS mean, stronger over all of the analyzed domain in the $40 \mathrm{~km}-\mathrm{P}$ than in the $5 \mathrm{~km}-\mathrm{E}$ simulation.

- The thermodynamic structure of the atmosphere in the $40 \mathrm{~km}-\mathrm{P}$ simulation is more supportive of the development of clouds and precipitation. The convective inhibition is lower in the $40 \mathrm{~km}-\mathrm{P}$ simulation compared to the $5 \mathrm{~km}$-E simulation due to the atmosphere being less stable.

- The $40 \mathrm{~km}-\mathrm{P}$ simulation is moister than the $5 \mathrm{~km}-\mathrm{E}$ simulation. This is especially true for the region between 15 and $25^{\circ} \mathrm{N}$, which coincides with the region of higher precipitation in the $40 \mathrm{~km}-\mathrm{P}$ simulation compared to the $5 \mathrm{~km}-\mathrm{E}$ simulation. The strength of moisture transport from the ocean to the African continent depends on the ocean region; over the Gulf of Guinea, the moisture transport is stronger in the $5 \mathrm{~km}$-E simulation, but the moisture transport from the tropical east Atlantic is stronger in the $40 \mathrm{~km}-\mathrm{P}$ simulation. More importantly, we found more evapotranspiration in the $40 \mathrm{~km}-\mathrm{P}$ than in the $5 \mathrm{~km}-\mathrm{E}$ simulation. The higher evapotranspiration rate is due to a higher soil moisture content throughout the whole simulation period. This is due to much weaker runoff in the $40 \mathrm{~km}-\mathrm{P}$ than in the $5 \mathrm{~km}-\mathrm{E}$ simulation. These differences in runoff result from substantially different precipitation characteristics. In the $40 \mathrm{~km}-\mathrm{P}$ simulation, light precipitation can be stored by the soil more easily. The moister soils favor evapotranspiration, which then makes it easier to trigger convection and to produce precipitation. In contrast, the $5 \mathrm{~km}$ E simulation exhibits much more intense precipitation events which occur less frequently and more locally, producing strong runoff and preventing the soil moisture from being refilled by precipitation. The drier conditions, especially in the transition zone of the Sahel region, hamper the development of convection and precipitation in the $5 \mathrm{~km}-\mathrm{E}$ simulation compared to the $40 \mathrm{~km}$ $\mathrm{P}$ simulation.

We conclude that using regional climate simulations using resolved, i.e., explicitly resolved, deep convection does not necessarily produce more precipitation in the mid-Holocene Sahara-Sahel region than simulations with parameterized deep convection. However, we have shown that the precipitation characteristics, in particular the absence of permanent light rainfall and more intense convective events in the simulations with resolved deep convection, are closer to what one would expect.

Our study pinpoints to the key role that soil hydrology may take in controlling the amount of rainfall in simulations with explicitly resolved convection. On the one hand, the used land-surface scheme might be limited to store large moisture amounts in the soil. On the other hand, it is not able to create overground lakes and wetlands in mid-Holocene climate simulations. However, these local moisture sources in the midHolocene Sahara-Sahel region might involve important local feedback mechanisms in simulations with explicitly resolved convection. To investigate these possible limitations of our simulations, the atmosphere-soil hydrology interaction will be subject to further numerical experiments in which we will also include the effect of a more vegetated "Green Sahara" on the difference between simulations with resolved and parameterized deep convection. 


\section{Appendix A: Analysis of $10 \mathrm{~km}$ simulations}

Here, we present the figures that we analyzed in the main paper again for the parameterized and explicitly resolved convection simulation with $10 \mathrm{~km}$ horizontal resolution.

In Fig. 4a and in the corresponding section, we argued that the meridional distribution of precipitation in the WA domain (Fig. 1) is more similar between the 40 and $10 \mathrm{~km}-\mathrm{P}$ simulations and between the 5 and $10 \mathrm{~km}-\mathrm{E}$ simulations, respectively, than between the $10 \mathrm{~km}-\mathrm{P}$ and $10 \mathrm{~km}-\mathrm{E}$ simulations. Here, we want to analyze the $10 \mathrm{~km}$ simulations a bit more carefully. The $10 \mathrm{~km}-\mathrm{P}$ simulation produces more precipitation than the $10 \mathrm{~km}-\mathrm{E}$ simulation. Especially interesting for us is the higher precipitation north of around $13^{\circ} \mathrm{N}$. Similar to the $40 \mathrm{~km}-\mathrm{P}$ simulation, the $10 \mathrm{~km}-\mathrm{P}$ simulation exhibits a double precipitation peak, which is absent in the $10 \mathrm{~km}-\mathrm{E}$ simulation. In the following, we show that the mechanisms described in the main paper also hold for the $10 \mathrm{~km}-\mathrm{P}$ and $10 \mathrm{~km}-\mathrm{E}$ simulations.

\section{A1 Large-scale circulation}

Figure A1 shows that the SHL is stronger and extends further west in the $10 \mathrm{~km}-\mathrm{P}$ than in the $10 \mathrm{~km}-\mathrm{E}$ simulation. In contrast to the $40 \mathrm{~km}-\mathrm{P}$ and $5 \mathrm{~km}-\mathrm{E}$, the pressure gradient between the SHL and the high pressure system over the Gulf of Guinea is stronger in the $10 \mathrm{~km}-\mathrm{P}$ than in the $10 \mathrm{~km}-\mathrm{E}$ simulation (Fig. A1a and b). This drives stronger winds in the Gulf of Guinea in the $10 \mathrm{~km}-\mathrm{P}$ simulation.
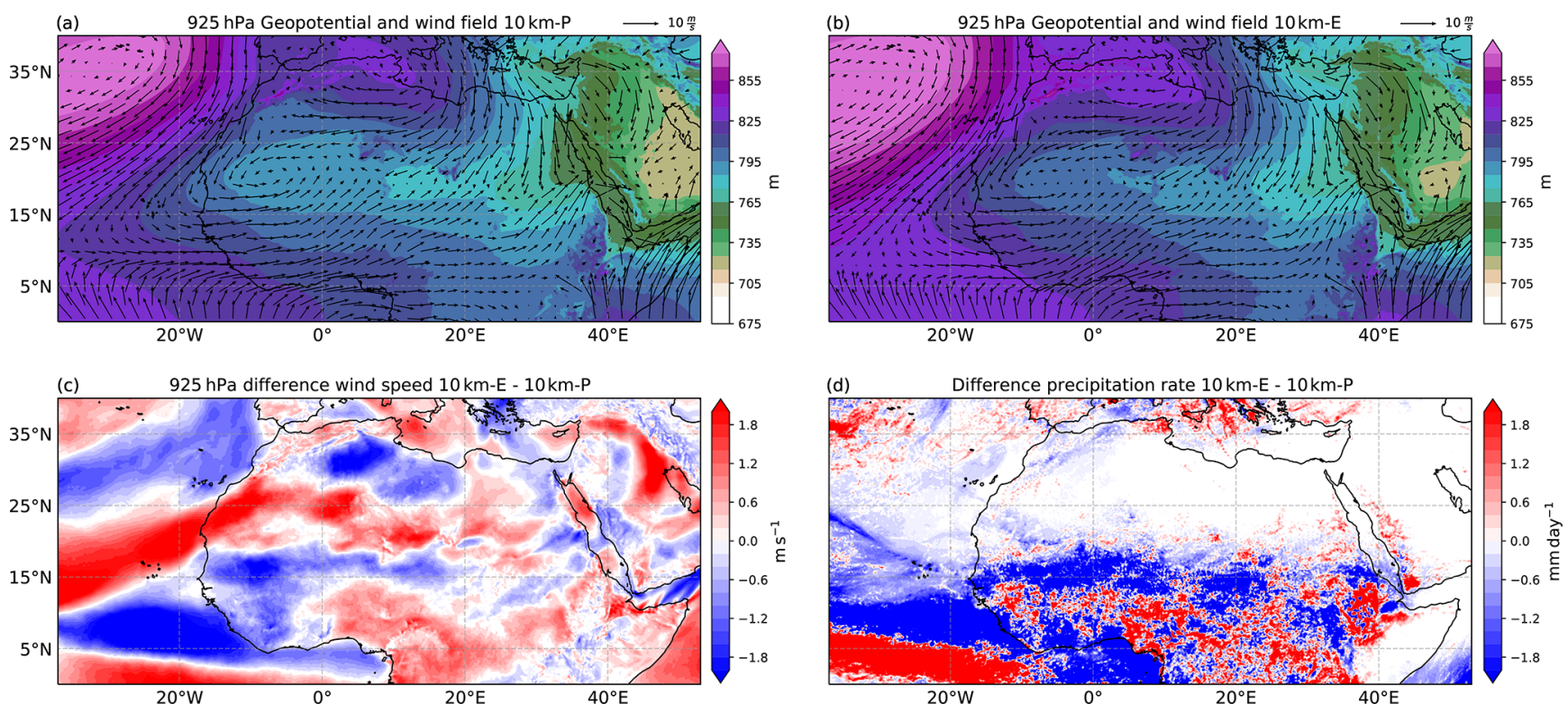

Figure A1. The same as Fig. 5 but for the $10 \mathrm{~km}-\mathrm{P}$ and $10 \mathrm{~km}-\mathrm{E}$ simulations. 
Table A1. The same as Table 1 but for the $10 \mathrm{~km}-\mathrm{P}$ and $10 \mathrm{~km}-\mathrm{E}$ simulations.

\begin{tabular}{llrr}
\hline & & $10 \mathrm{~km}-\mathrm{P}$ & $10 \mathrm{~km}-\mathrm{E}$ \\
\hline \multirow{2}{*}{ Coastal } & CAPE $\left(\mathrm{J} \mathrm{kg}^{-1}\right)$ & 771.5 & 942.6 \\
& $\mathrm{CIN}\left(\mathrm{J} \mathrm{kg}^{-1}\right)$ & -29.7 & -35.9 \\
& $T-T_{d}\left({ }^{\circ} \mathrm{C}\right)$ & 5.3 & 5.8 \\
\hline \multirow{2}{*}{ Sahel } & $\mathrm{CAPE}\left(\mathrm{J} \mathrm{kg}^{-1}\right)$ & 772.3 & 381.2 \\
& $\mathrm{CIN}\left(\mathrm{J} \mathrm{kg}^{-1}\right)$ & -187.6 & -227.5 \\
& $T-T_{d}\left({ }^{\circ} \mathrm{C}\right)$ & 13.6 & 17.6 \\
\hline \multirow{2}{*}{ Sahara } & $\mathrm{CAPE}\left(\mathrm{J} \mathrm{kg}^{-1}\right)$ & 60.8 & 5.7 \\
& $\mathrm{CIN}\left(\mathrm{J} \mathrm{kg}{ }^{-1}\right)$ & -121.9 & -31.4 \\
& $T-T_{d}\left({ }^{\circ} \mathrm{C}\right)$ & 29.9 & 32.9 \\
\hline
\end{tabular}

\section{A2 Thermodynamics}

We present the mean CAPE and CIN values in Table A1, similar to Table 1 in Sect. 3.3. We show that the thermodynamic structure of the atmosphere in the $10 \mathrm{~km}-\mathrm{P}$ and the $10 \mathrm{~km}-\mathrm{E}$ simulations is similar to that in the $40 \mathrm{~km}-\mathrm{P}$ and $5 \mathrm{~km}-\mathrm{E}$ simulations, respectively (Sect. 3.3). In particular, the differences between explicit and parameterized convection over the Sahel, with a larger dew-point depression and an atmosphere less conductive to convection, are also clearly visible when comparing the $10 \mathrm{~km}-\mathrm{P}$ to the $10 \mathrm{~km}-\mathrm{E}$ simulation.

\section{A3 Moisture field and moisture transport}

The more humid conditions revealed by the thermodynamics are confirmed by the vertical moisture cross section (Fig. A3) of specific (Fig. A3a and b) and relative humidity (Fig. A3c and $\mathrm{d}$ ). In the lowest atmosphere levels, the $10 \mathrm{~km}-\mathrm{P}$ simulation is more humid than the $10 \mathrm{~km}-\mathrm{E}$ simulation, especially north of $15^{\circ} \mathrm{N}$ - the transition region where we also find the higher precipitation rates (Fig. 4).

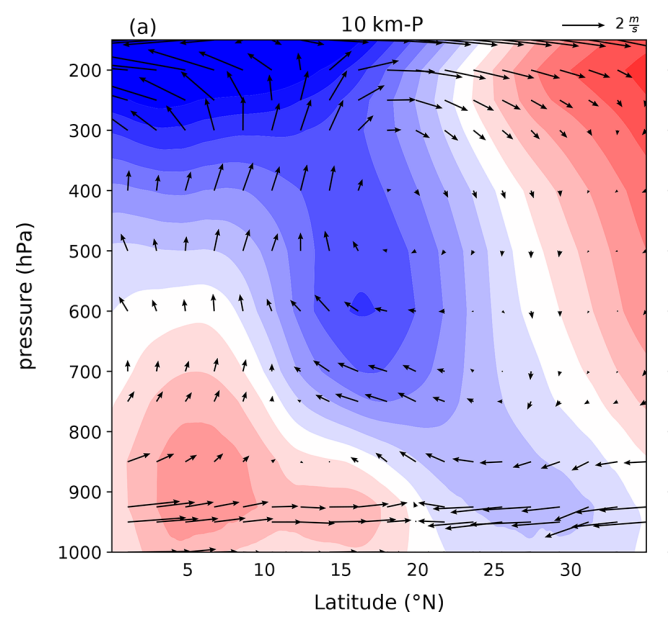

The horizontal transport of moisture from the Atlantic and the Gulf of Guinea region towards the African continent is higher in the $10 \mathrm{~km}-\mathrm{P}$ than in the $10 \mathrm{~km}-\mathrm{E}$ simulation, consistent with the moisture cross section (Fig. A3). The moisture import from the Mediterranean Sea is similar in both simulations. The mean moisture transport in the WA domain is 84.5 and $69.6 \mathrm{~kg} \mathrm{~m}^{-1} \mathrm{~s}^{-1}$ in the $10 \mathrm{~km}-\mathrm{P}$ and $10 \mathrm{~km}-\mathrm{E}$ simulations, respectively. Therefore, the higher moisture transport supports the generally moister conditions revealed by Fig. A3.

\section{A4 Land-atmosphere coupling}

The coupling of the atmosphere and the surface is very similar, as described in Sect. 3.5. Figure A5a shows higher evapotranspiration over land at all latitudes in the $10 \mathrm{~km}-\mathrm{P}$ compared to the $10 \mathrm{~km}-\mathrm{E}$ simulation. The higher evaporation is consistent with the higher soil moisture values shown in Fig. A5b. The higher evapotranspiration rates in the $10 \mathrm{~km}$ $\mathrm{P}$ simulation are consistent with weaker surface and groundwater runoff compared to the $10 \mathrm{~km}-\mathrm{E}$ simulation. With other words, the soil loses less water into runoff and stays moister. This is forced by differences in the precipitation intensity and its spatial distribution. Figure A5d shows that the $10 \mathrm{~km}-\mathrm{P}$ simulation produces more often (higher probability values) light and widespread precipitation compared to the $10 \mathrm{~km}-\mathrm{E}$ simulation.

Figure A2. The same as Fig. 6 but for the $10 \mathrm{~km}-\mathrm{P}$ and $10 \mathrm{~km}-\mathrm{E}$ simulations. 

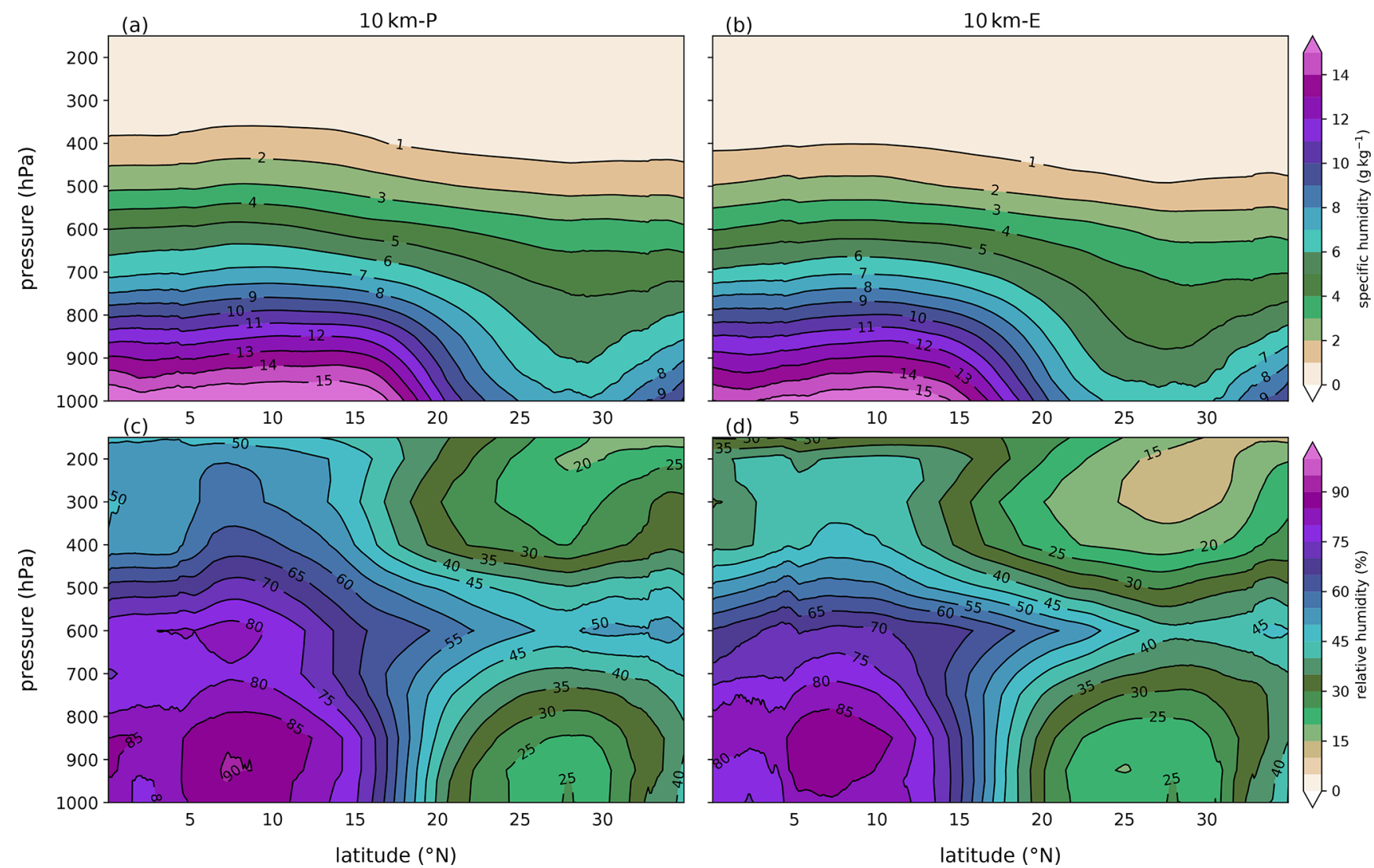

Figure A3. The same as Fig. 8 but for the $10 \mathrm{~km}-\mathrm{P}$ and $10 \mathrm{~km}-\mathrm{E}$ simulations.
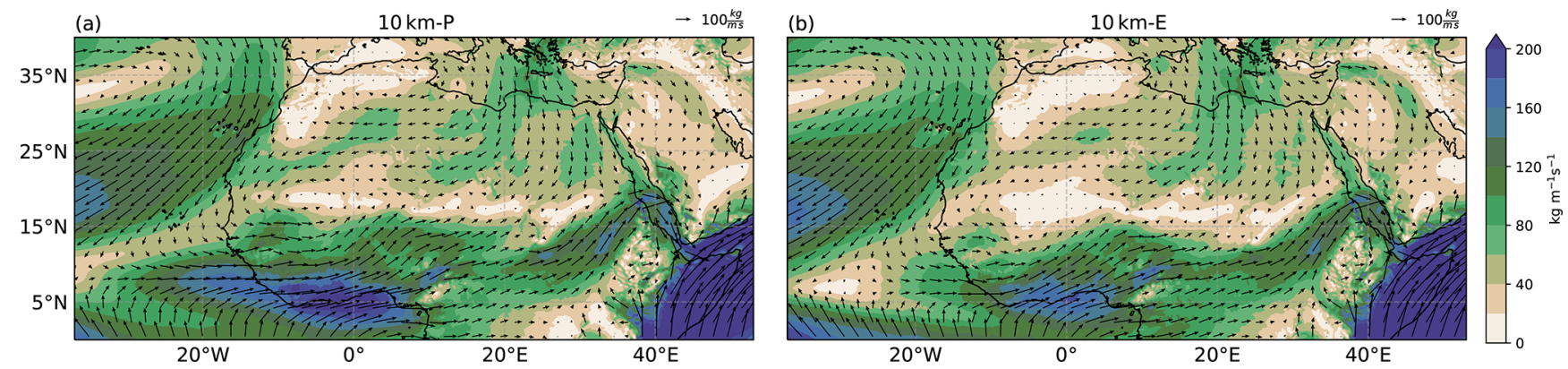

Figure A4. The same as Fig. 9 but for the $10 \mathrm{~km}-\mathrm{P}$ and $10 \mathrm{~km}-\mathrm{E}$ simulations. 

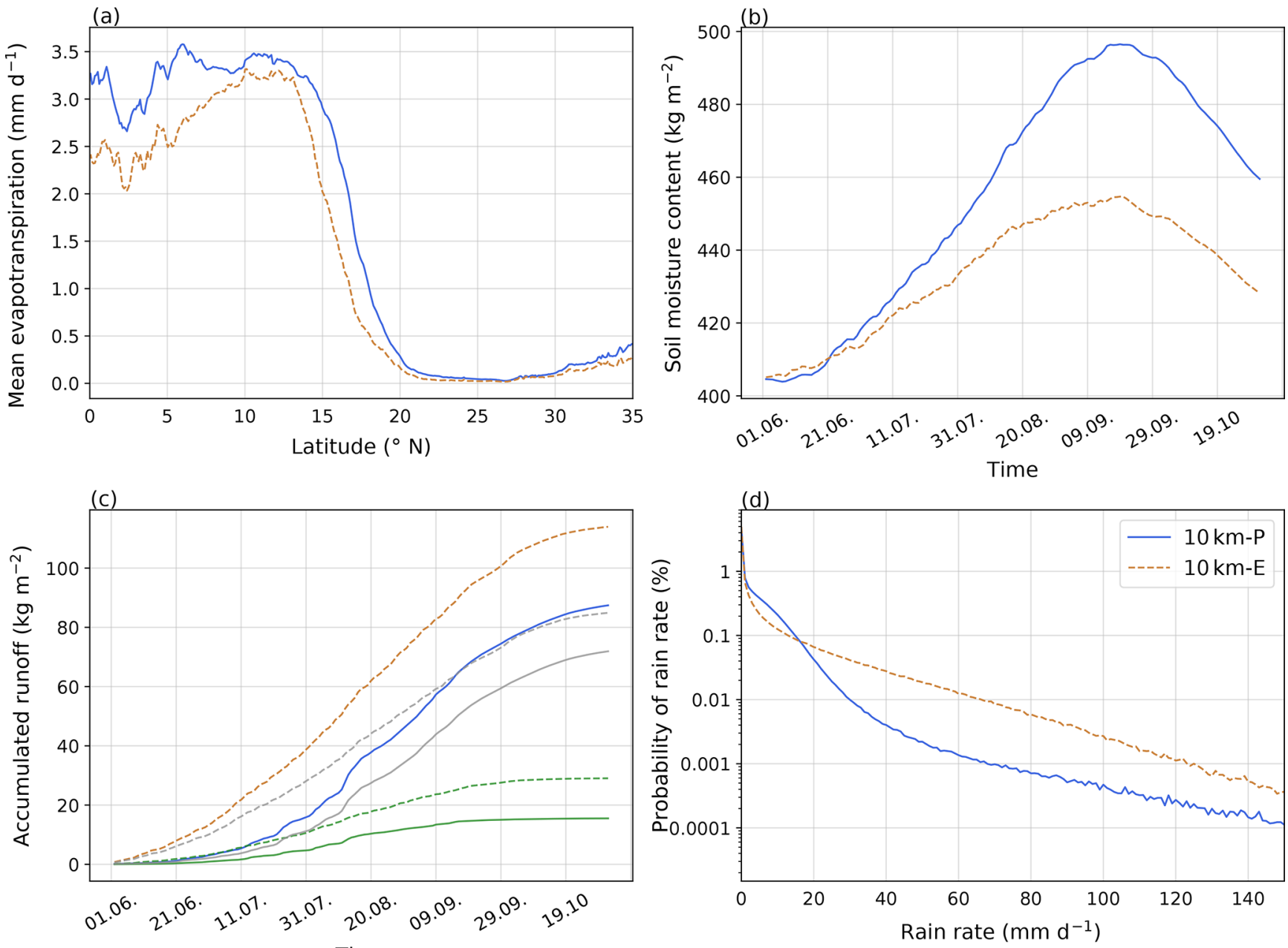

Figure A5. The same as Fig. 10 but for the $10 \mathrm{~km}-\mathrm{P}$ and $10 \mathrm{~km}-\mathrm{E}$ simulations. 
Code availability. The scripts used in the analysis and other supplementary information that may be useful in reproducing the author's work can be obtained from MPG.PuRe (http://hdl.handle.net/ 21.11116/0000-0007-6597-D, last access: 29 July 2021, Jungandreas et al., 2021b).

Data availability. Daily-mean model output from the simulations to reproduce the main results can be downloaded from DKRZ LTA DOCU (Jungandreas et al., 2021a, https://doi.org/10.26050/ WDCC/ICON-NWP_mH_convection.)

Author contributions. $\mathrm{CH}$ and $\mathrm{MC}$ designed the research project and the experiments. LJ performed the simulations and analysis. $\mathrm{CH}, \mathrm{JB}$ and $\mathrm{MC}$ gave input, ideas and feedback to the analysis of the simulations. LJ prepared the manuscript with contributions from all co-authors.

Competing interests. The authors declare that they have no conflict of interest.

Acknowledgements. We thank Jürgen Bader and Anne Dallmeyer for valuable discussions and comments. Further, we thank Roberta D'Agostino for internal review and acknowledge Reiner Schnur for technical support. This research was supported by the International Max Planck Research School on Earth System Modelling (IMPRS-ESM), Hamburg. The model simulations were performed at the Deutsche Klimarechenzentrum (DKRZ).

Financial support. The article processing charges for this openaccess publication were covered by the Max Planck Society.

Review statement. This paper was edited by Ran Feng and reviewed by Aiko Voigt and two anonymous referees.

\section{References}

Bartlein, P. J., Harrison, S., Brewer, S., Connor, S., Davis, B., Gajewski, K., Guiot, J., Harrison-Prentice, T., Henderson, A., Peyron, O., Prentice, I. C., Scholze, M., Seppä, H., Shuman, B., Sugita, S., Thompson, R. S., Viau, A. E., Williams, J., and $\mathrm{Wu}, \mathrm{H}$.: Pollen-based continental climate reconstructions at 6 and 21 ka: a global synthesis, Clim. Dynam., 37, 775-802, 2011.

Bechtold, P., Semane, N., Lopez, P., Chaboureau, J.-P., Beljaars, A., and Bormann, N.: Representing equilibrium and nonequilibrium convection in large-scale models, J. Atmos. Sci., 71, 734-753, 2014.

Berthou, S., Rowell, D. P., Kendon, E. J., Roberts, M. J., Stratton, R. A., Crook, J. A., and Wilcox, C.: Improved climatological precipitation characteristics over West Africa at convectionpermitting scales, Clim. Dynam., 53, 1991-2011, 2019.
Braconnot, P., Joussaume, S., Marti, O., and De Noblet, N.: Synergistic feedbacks from ocean and vegetation on the African monsoon response to mid-Holocene insolation, Geophys. Res. Lett., 26, 2481-2484, 1999.

Braconnot, P., Joussaume, S., De Noblet, N., and Ramstein, G.: Mid-Holocene and last glacial maximum African monsoon changes as simulated within the paleoclimate modelling intercomparison project, Global Planet. Change, 26, 51-66, 2000.

Braconnot, P., Harrison, S. P., Joussaume, S., Hewitt, C. D., Kitoch, A., Kutzbach, J. E., Liu, Z., Otto-Bliesner, B., Syktus, J., and Weber, S.: Evaluation of PMIP coupled ocean-atmosphere simulations of the Mid-Holocene, in: Past climate variability through Europe and Africa, Springer, Dordrecht, 515-533, 2004.

Braconnot, P., Harrison, S. P., Kageyama, M., Bartlein, P. J., Masson-Delmotte, V., Abe-Ouchi, A., Otto-Bliesner, B., and Zhao, Y.: Evaluation of climate models using palaeoclimatic data, Nat. Clim. Change, 2, 417-424, 2012.

Brierley, C. M., Zhao, A., Harrison, S. P., Braconnot, P., Williams, C. J. R., Thornalley, D. J. R., Shi, X., Peterschmitt, J.-Y., Ohgaito, R., Kaufman, D. S., Kageyama, M., Hargreaves, J. C., Erb, M. P., Emile-Geay, J., D’Agostino, R., Chandan, D., Carré, M., Bartlein, P. J., Zheng, W., Zhang, Z., Zhang, Q., Yang, H., Volodin, E. M., Tomas, R. A., Routson, C., Peltier, W. R., OttoBliesner, B., Morozova, P. A., McKay, N. P., Lohmann, G., Legrande, A. N., Guo, C., Cao, J., Brady, E., Annan, J. D., and Abe-Ouchi, A.: Large-scale features and evaluation of the PMIP4-CMIP6 midHolocene simulations, Clim. Past, 16, 18471872, https://doi.org/10.5194/cp-16-1847-2020, 2020.

Claussen, M. and Gayler, V.: The greening of the Sahara during the mid-Holocene: results of an interactive atmosphere-biome model, Global Ecol. Biogeogr., 6, 369-377, 1997.

Claussen, M., Dallmeyer, A., and Bader, J.: Theory and modeling of the African humid period and the green Sahara, in: Oxford Research Encyclopedia of Climate Science, Oxford University press, 2017.

Cook, K. H.: Generation of the African easterly jet and its role in determining West African precipitation, J. Climate, 12, 11651184, 1999.

Dallmeyer, A., Claussen, M., Lorenz, S. J., and Shanahan, T.: The end of the African humid period as seen by a transient comprehensive Earth system model simulation of the last 8000 years, Clim. Past, 16, 117-140, https://doi.org/10.5194/cp16-117-2020, 2020.

Dirmeyer, P. A., Cash, B. A., Kinter, J. L., Jung, T., Marx, L., Satoh, M., Stan, C., Tomita, H., Towers, P., Wedi, N., Achuthavarier, D., Adams, J. M., Altshuler, E. L., Huang, B., Jin, E. K., and Manganello, J.: Simulating the diurnal cycle of rainfall in global climate models: Resolution versus parameterization, Clim. Dynam., 39, 399-418, 2012.

Dixit, V., Sherwood, S., Geoffroy, O., and Mantsis, D.: The role of nonlinear drying above the boundary layer in the mid-holocene African monsoon, J. Climate, 31, 233-249, 2018.

Druyan, L. M. and Koster, R. D.: Sources of Sahel precipitation for simulated drought and rainy seasons, J. Climate, 2, 1438-1446, 1989.

Fiedler, S., Crueger, T., D’Agostino, R., Peters, K., Becker, T., Leutwyler, D., Paccini, L., Burdanowitz, J., Buehler, S. A., Cortes, A. U., Dauhut, T., Dommenget, D., Fraedrich, K., Jungandreas, L., Maher, N., Naumann, A. K., Rugenstein, M., 
Sakradzija, M., Schmidt, H., Sielmann, F., Stephan, C., Timmreck, C., Zhu, X., and Stevens, B.: Simulated Tropical Precipitation Assessed across Three Major Phases of the Coupled Model Intercomparison Project (CMIP), Mon. Weather Rev., 148, 3653-3680, 2020.

Grist, J. P. and Nicholson, S. E.: A study of the dynamic factors influencing the rainfall variability in the West African Sahel, J. Climate, 14, 1337-1359, 2001.

Harrison, S. P., Bartlein, P., Izumi, K., Li, G., Annan, J., Hargreaves, J., Braconnot, P., and Kageyama, M.: Evaluation of CMIP5 palaeo-simulations to improve climate projections, Nat. Clim. Change, 5, 735-743, 2015.

Hewitt, C. D. and Mitchell, J. F.: A fully coupled GCM simulation of the climate of the mid-Holocene, Geophys. Res. Lett., 25, 361-364, 1998

Hohenegger, C., Kornblueh, L., Klocke, D., Becker, T., Cioni, G., Engels, J. F., Schulzweida, U., and Stevens, B.: Climate statistics in global simulations of the atmosphere, from 80 to $2.5 \mathrm{~km}$ grid spacing, J. Meteorol. Soc. Jpn. Ser. II, 98, 73-91, https://doi.org/10.2151/jmsj.2020-005, 2020

Jolly, D., Prentice, I. C., Bonnefille, R., Ballouche, A., Bengo, M., Brenac, P., Buchet, G., Burney, D., Cazet, J.-P., Cheddadi, R., Edorh, T., Elenga, H., Elmoutaki, S., Guiot, J., Laarif, F., Lamb, H., Lezine, A.-M., Maley, J., Mbenza, M., Peyron, O., Reille, M., Reynaud-Farrera, I., Riollet, G., Ritchie, J. C., Roche, E., Scott, L., Ssemmanda, I., Straka, H., Umer, M., Van Campo, E., Vilimumbalo, S., Vincens, A., and Waller, M.: Biome reconstruction from pollen and plant macrofossil data for Africa and the Arabian peninsula at 0 and 6000 years, J. Biogeogr., 25, 1007-1027, 1998.

Joussaume, S., Taylor, K. E., Braconnot, P., Mitchell, J. F. B., Kutzbach, J. E., Harrison, S. P., Prentice, I. C., Broccoli, A. J., Abe-Ouchi, A., Bartlein, P. J., Bonfils, C., Dong, B., Guiot, J., Herterich, K., Hewitt, C. D., Jolly, D., Kim, J. W., Kislov, A., Kitoh, A., Loutre, M. F., Masson, V., McAvaney, B., McFarlane, N., de Noblet, N., Peltier, W. R., Peterschmitt, J. Y., Pollard, D., Rind, D., Royer, J. F., Schlesinger, M. E., Syktus, J., Thompson, S., Valdes, P., Vettoretti, G., Webb, R. S., and Wyputta, U.: Monsoon changes for 6000 years ago: results of 18 simulations from the Paleoclimate Modeling Intercomparison Project (PMIP), Geophys. Res. Lett., 26, 859-862, 1999.

Jungandreas, L., Hohenegger, C., and Claussen, M.: ICONNWP simulations of the West African Monsoon during the mid-Holocene using parameterized and explicit convection and present-day land surface, World Data Center for Climate (WDCC) at DKRZ [data set], https://doi.org/10.26050/WDCC/ICON-NWP_mH_convection, 2021a.

Jungandreas, L., Hohenegger, C., and Claussen, M.: The influence of the representation of convection on the mid-Holocene West African Monsoon - Scripts, MPG.PuRe [model code], available at: http://hdl.handle.net/21.11116/0000-0007-6597-D, last access: 29 July $2021 \mathrm{~b}$.

Klocke, D., Brueck, M., Hohenegger, C., and Stevens, B.: Rediscovery of the doldrums in storm-resolving simulations over the tropical Atlantic, Nat. Geosci., 10, 891-896, 2017.

Kutzbach, J. and Otto-Bliesner, B.: The sensitivity of the AfricanAsian monsoonal climate to orbital parameter changes for
9000 years BP in a low-resolution general circulation model, J. Atmos. Sci., 39, 1177-1188, 1982.

Kutzbach, J. E. and Guetter, P. J.: The influence of changing orbital parameters and surface boundary conditions on climate simulations for the past 18000 years, J. Atmos. Sci., 43, 1726-1759, 1986.

Kutzbach, J. E. and Liu, Z.: Response of the African monsoon to orbital forcing and ocean feedbacks in the middle Holocene, Science, 278, 440-443, 1997.

Lélé, M. I., Leslie, L. M., and Lamb, P. J.: Analysis of low-level atmospheric moisture transport associated with the West African Monsoon, J. Climate, 28, 4414-4430, 2015.

Levis, S., Bonan, G. B., and Bonfils, C.: Soil feedback drives the mid-Holocene North African monsoon northward in fully coupled CCSM2 simulations with a dynamic vegetation model, Clim. Dynam., 23, 791-802, 2004.

Marsham, J. H., Dixon, N. S., Garcia-Carreras, L., Lister, G. M., Parker, D. J., Knippertz, P., and Birch, C. E.: The role of moist convection in the West African monsoon system: Insights from continental-scale convection-permitting simulations, Geophys. Res. Lett., 40, 1843-1849, 2013.

Nicholson, S. E.: The West African Sahel: A review of recent studies on the rainfall regime and its interannual variability, ISRN Meteorology, 2013, 453521, https://doi.org/10.1155/2013/453521, 2013.

Nicholson, S. E. and Grist, J.: A conceptual model for understanding rainfall variability in the West African Sahel on interannual and interdecadal timescales, Int. J. Climatol., 21, 1733-1757, 2001.

Pausata, F. S., Messori, G., and Zhang, Q.: Impacts of dust reduction on the northward expansion of the African monsoon during the Green Sahara period, Earth Planet. Sc. Lett., 434, 298-307, 2016.

Pearson, K., Lister, G., Birch, C., Allan, R., Hogan, R., and Woolnough, S.: Modelling the diurnal cycle of tropical convection across the 'grey zone', Q. J. Roy. Meteor. Soc., 140, 491-499, 2014.

Peyron, O., Jolly, D., Braconnot, P., Bonnefille, R., Guiot, J., Wirrmann, D., and Chalié, F.: Quantitative reconstructions of annual rainfall in Africa 6000 years ago: Model-data comparison, J. Geophys. Res., 111, D24110, https://doi.org/10.1029/2006JD007396, 2006.

Randall, D., Khairoutdinov, M., Arakawa, A., and Grabowski, W.: Breaking the cloud parameterization deadlock, B. Am. Meteorol. Soc., 84, 1547-1564, 2003.

Savenije, H. H.: The runoff coefficient as the key to moisture recycling, J. Hydrol., 176, 219-225, 1996.

Stephens, G. L., L'Ecuyer, T., Forbes, R., Gettelmen, A., Golaz, J.C., Bodas-Salcedo, A., Suzuki, K., Gabriel, P., and Haynes, J.: Dreary state of precipitation in global models, J. Geophys. Res., 115, D24211, https://doi.org/10.1029/2010JD014532, 2010.

Stevens, B., Satoh, M., Auger, L., Biercamp, J., Bretherton, C. S., Chen, X., Düben, P., Judt, F., Khairoutdinov, M., Klocke, D., Kodama, C., Kornblueh, L., Lin, S.-J., Neumann, P., Putman, W. M., Röber, N., Shibuya, R., Vanniere, B., Vidale, P. L., Wedi, N., and Zhou, L.: DYAMOND: The DYnamics of the atmospheric general circulation modeled on non-hydrostatic domains, Prog. Earth Planet. Sci., 6, 61, https://doi.org/10.1186/s40645019-0304-z, 2019. 
Street-Perrott, F., Mitchell, J., Marchand, D., and Brunner, J.: Milankovitch and albedo forcing of the tropical monsoons: a comparison of geological evidence and numerical simulations for 9000 yBP, Earth Env. Sci. T. R. So., 81, 407-427, 1990.

Thompson, A. J., Skinner, C. B., Poulsen, C. J., and Zhu, J.: Modulation of mid-Holocene African rainfall by dust aerosol direct and indirect effects, Geophys. Res. Lett., 46, 3917-3926, 2019.

Thorncroft, C. D., Nguyen, H., Zhang, C., and Peyrillé, P.: Annual cycle of the West African monsoon: regional circulations and associated water vapour transport, Q. J. R. Meteor. So., 137, 129147, 2011.

Tiedtke, M.: A comprehensive mass flux scheme for cumulus parameterization in large-scale models, Mon. Weather Rev., 117, 1779-1800, 1989.

Tierney, J. E., Pausata, F. S., and deMenocal, P. B.: Rainfall regimes of the Green Sahara, Sci. Adv., 3, e1601503, https://doi.org/10.1126/sciadv.1601503, 2017.
Vamborg, F., Brovkin, V., and Claussen, M.: The effect of a dynamic background albedo scheme on Sahel/Sahara precipitation during the mid-holocene, CliPD, 6, 2335-2370, 2010.

Yang, G.-Y. and Slingo, J.: The diurnal cycle in the tropics, Mon. Weather Rev., 129, 784-801, 2001.

Yu, G. and Harrison, S.: An evaluation of the simulated water balance of Eurasia and northern Africa at $6000 \mathrm{y} \mathrm{BP}$ using lake status data, Clim. Dynam., 12, 723-735, 1996.

Zängl, G., Reinert, D., Rípodas, P., and Baldauf, M.: The ICON (ICOsahedral Non-hydrostatic) modelling framework of DWD and MPI-M: Description of the non-hydrostatic dynamical core, Q. J. Roy. Meteor. Soc., 141, 563-579, 2015. 